Ks. Piotr SZCZUR*

\title{
ANTIOCHIA SYRYJSKA JAKO OŚRODEK ASCEZY I MONASTYCYZMU W DRUGIEJ POLOWIE IV W.
}

Starożytna Antiochia, zwana też Antiochią Syryjską (obecnie Antakya w południowej Turcji, stolica prowincji Hatay) położona była w południowo-

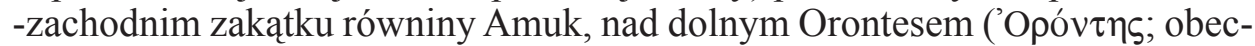
nie tur. Asi Neri, arab. Nahr al-Asi), w miejscu, w którym rzeka przecina góry, około $30 \mathrm{~km}$ od ujścia do Morza Śródziemnego. Właśnie w tym miejscu, mię-

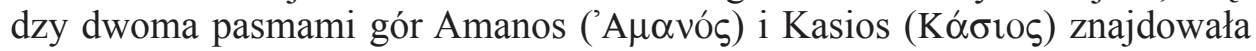
się żyzna dolina.

W dolinie między lewym brzegiem rzeki a górą Silpios ( $\Sigma \hat{i} \lambda \pi \imath \circ)$ wznoszącą się na wysokość ponad $500 \mathrm{~m}$ n.p.m., rozciagał się stosunkowo równy teren, na którym wzniesiono miasto. Założył je jeden z dowódców wojskowych Aleksandra Wielkiego (356-323 prz. Chr.), Seleukos I Nikator (312-281 prz. Chr.) $)^{2}$ ok. 300 r. prz. Chr. ${ }^{3}$, i nazwał imieniem swego ojca Antiocha ${ }^{4}$. Po-

* Ks. dr hab. Piotr Szczur, prof. KUL - kierownik Katedry Historii Kościoła w Starożytności i Średniowieczu w Instytucie Historii Kościoła i Patrologii na Wydziale Teologii Katolickiego Uniwersytetu Lubelskiego Jana Pawła II; e-mail: p_szczur@kul.pl.

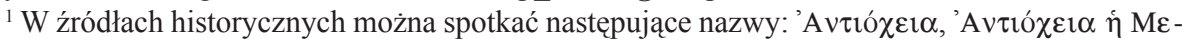

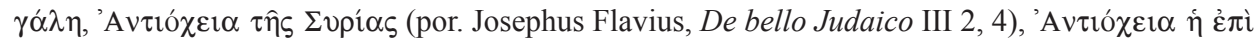

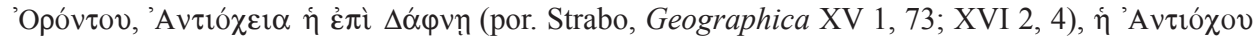

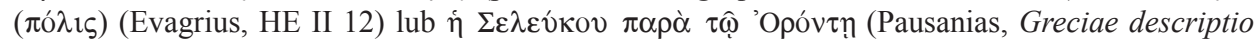
VIII 33, 3).

${ }^{2}$ W 321 r. prz. Chr. diadochowie, którzy wcześniej doprowadzili do zabójstwa regenta Perdikkasa (ok. 365-320 prz. Chr.), powierzyli Babilon Seleukosowi, dowódcy macedońskiej kawalerii. Jednak w 316 r. satrapa Frygii Antygonos Monophtalmos (382-301 prz. Chr.) wypędził Seleukosa z Babilonu. Seleukos schronił się w Egipcie u Ptolemeusza I Sotera (367-283). W 312 r. powrócił do Babilonu, odzyskał władzę i bronił swej prowincji przed atakami Antygonosa i jego syna Demetriosa (337-283 prz. Chr.). W 301 r. Antygonos poniósł śmierć w bitwie pod Ipsos we Frygii. Wówczas Seleukos przyjął tytuł Nikator. Seleukos został zasztyletowany przez Ptolemeusza Keraunosa $(† 279$ prz. Chr.), syna Ptolemeusza I, w sierpniu lub wrześniu 281 r. Szerzej zob. A.J. Sachs - D.J. Wiseman, A Babylonian King List of the Hellenistic Period, „Iraq” 16 (1954) 202-211 (spec. s. 205-206); G. Roux, Mezopotamia, thum. B. Kowalska - J. Kozłowska, Warszawa 1998, 333-334.

${ }^{3}$ Słynny antiocheński retor - Libaniusz w Mowie na cześć Antiochii (Oratio 11, 72-77), przytacza legendę, w której za założyciela miasta uchodzi Aleksander Macedoński.

${ }^{4}$ Por. Strabo, Geographica XVI 2, 4. G. Haddad (Aspects of Social Life in Antioch, Chicago 1949, 3) podaje inną, lecz mało prawdopodobną wersję, że Antiochia otrzymała imię Antiocha, syna 
czątkowo miasto rozwijało się na lewym brzegu Orontesu, lecz z czasem, z powodu wielkiego napływu ludności, rozszerzyło swe granice również na prawy

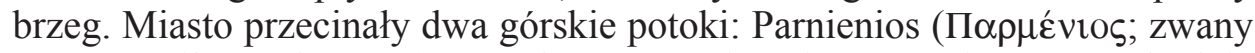
też Onopniktes - 'Ovo

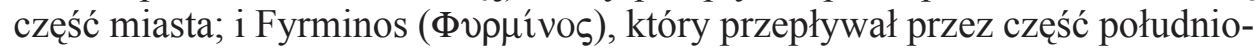
wo-zachodnią.

Miasto bardzo szybko rozwijało się i już ok. 170 r. prz. Chr. za Antiocha IV Epifanesa (175-163 prz. Chr.) zaczęło zajmować stoki góry Silpios ${ }^{5}$. Tak rozbudowana Antiochia była zaliczana w tym czasie (połowa II w. prz. Chr.) do czołowych miast starożytnych. Połączenie strategicznego położenia naturalnego i piękna Antiochii sprawiło, że w krótkim czasie stała się ona centrum administracyjnym, militarnym, handlowym oraz kulturalnym.

Dla rozważań przedstawionych $\mathrm{w}$ niniejszym opracowaniu istotna jest pewna cecha topograficzna miasta, a mianowicie sąsiedztwo dwóch gór: Silpios i Staurin, wznoszących się ponad miastem po jego południowo-wschodniej stronie ${ }^{6}$. Zamieszkałe obszary stoków tych gór zostały objęte nowymi murami miejskimi wzniesionymi za cesarza Tyberiusza (16 XI 42 prz. Chr. - 16 III 37; cesarz od 14)7. To właśnie tu, już od czasów apostolskich, rozkwitał chrześcijański ascetyzm przybierający różne formy, a w jaskiniach, grotach i prymitywnych domostwach położonych na bardziej stromych zboczach i szczytach gór Staurin i Silpios żyli mnisi wspominani przez Libaniusza (ok. 314-395) i opisani przez Jana Chryzostoma (ok. 349 - 14 IX 407) oraz Teodoreta z Cyru (ok. 386/393-457/466).

1. Ascetyzm miejski. Jan Chryzostom w napisanym na przełomie roku 381 i $382^{8}$, traktacie De Compunctione wymienił trzy stany chrześcijan: świeckich,

Seleukosa I Nikatora. Wydaje się, że Haddad bezkrytycznie zaczerpnął tę informację od Hermiasza Sozomena, który mówiąc o świątyni Apollona w Dafne, jest zdania, że ,podobno wzniósł ją Seleukos, ojciec Antiocha, od którego nazwę wzięło miasto Antiochia" (tenże, HE V 19, éd. J. Bidez - G.C. Hansen, SCh 495 (Livres: V-VI), Paris 2005, 196, tłum. S. Kazikowski: Hermiasz Sozomen, Historia Kościoła, Warszawa 1989, 339).

${ }^{5}$ Szerzej na temat rozwoju Antiochii za panowania Seleucydów (od Antiocha I do Antiocha IV) zob. G. Downey, A History of Antioch in Syria from Seleucus to the Arab Conquest, Princeton 1961, 87-107. Autor omawia rozwój miasta podkreślając rolę Antiocha IV Epifanesa, który w sposób szczególny wpisał się w historię Antiochii, gdyż prowadził zakrojone na bardzo szeroką skalę prace budowlane, znacznie rozbudowując miasto i powiększył je o nową „,dzielnicę”.

${ }^{6}$ Por. Libanius, Oratio 11, 199-200; A.J. Festugière, Antioche païenne et chrétienne. Libanius, Chrysostome et les moines de Syrie, Bibliothèque des Écoles Françaises d'Athènes et de Rome, Fascicule 194, Paris 1959, 41-42.

${ }^{7} \mathrm{Na}$ temat rozwoju miasta w czasach cesarza Tyberiusza, zob. Downey, A History of Antioch in Syria, s. 169-189.

${ }^{8}$ Por. J.N.D. Kelly, Ztote usta. Jan Chryzostom - asceta, kaznodzieja, biskup, thum. K. Krakowczyk, Bydgoszcz 2001, 53, gdzie autor umieszcza redakcję tekstu w okresie, gdy Jan był „młodym diakonem", a został nim w 380 lub 381 r. Święceń udzielił mu biskup Melecjusz. Zob. Palladius, Dialogus de vita Iohannis Chrysostomi 5, ed. A.M. Malingrey - P. Leclercq, SCh 341, Paris 1988, 


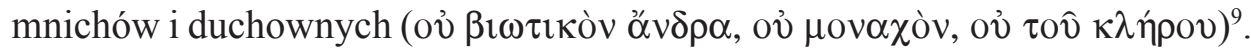
$\mathrm{Z}$ przytoczonego wyliczenia wynika, że Chryzostom nie traktował ascetów żyjących $\mathrm{w}$ mieście jako oddzielny stan funkcjonujący w Kościele. Można zatem wyciagnąć wniosek, że ascetami miejskimi byli zwykli chrześcijanie świeccy, ćwiczący się w cnotach i dążący do świętości. Ten wniosek zbieżny jest z postawą Złotoustego przyjmowaną wobec wiernych w Antiochii. Przykładowo w Homiliach na Ewangelie wedlug św. Mateusza ${ }^{10}$ Chryzostom wyjaśnia, że wszyscy chrześcijanie, nie tylko mnisi, ale i żyjący „w świecie”, są zobowiązani do tego, by być świętymi, gdyż te same prawa i te same zasady postępowania odnoszą się do każdego chrześcijanina, bez względu na to, czy jest pustelnikiem, czy żyje w małżeństwie. Nie wszystkie wskazówki Chryzostoma podobały się jego słuchaczom. Uważali oni, że Antiocheńczyk chce uczynić mnichów z wszystkich mieszkańców miasta ${ }^{11}$. Jedynym zaś motywem udzielania przez Chryzostoma rad i nagan była chęć, by wszyscy stali się przyzwoici i czyści ${ }^{12}$. Dlatego zachęcając do praktykowania ascezy i ćwiczenia się w cnotach thumaczy: „Nie wmawiaj sobie: «jestem człowiekiem światowym, mam żonę i dzieci, a to sprawa kapłanów i mnichów»" ${ }^{\prime 3}$.

110; Kelly, Ztote usta, s. 49; C. Tiersch, Johannes Chrysostomus in Konstantinopel (398-404). Weltsicht und Wirken eines Bischofs in der Hauptstadt des Oströmischen Reiches, Studien und Texte zu Antike und Christentum 6, Tübingen 2002, 60.

${ }^{9}$ Por. Joannes Chrysostomus, Ad Demetrium de compunctione lib. 1, 5, PG 47, 401.

${ }^{10}$ Większość uczonych jest zdania, że homilie te zostały wygłoszone w 390 lub 391 r. Najważniejsze opinie na ten temat sumuje Wendy Mayer (The Homilies of St John Chrysostom: Provenance. Reshaping the Foundations, OCA 273, Rome 2005, 267 [CPG 4424]).

${ }^{11}$ Por. Joannes Chrysostomus, In Matthaeum hom. 7, 7, PG 57, 82, tłum. J. Krystyniacki, ŹMT 18, Kraków 2000, 101: „Wprawdzie życzyłbym sobie tego [abyście zostali mnichami i udali się w góry] [...], ale do tego nie zmuszam". Z tego względu niektórzy uczeniu uważają, iż Jan Chryzostom chciał uczynić mnichów ze wszystkich chrześcijan. Por. Tiersch, Johannes Chrysostomus in Konstantinopel (398-404), s. 75; W. Mayer, John Chrysostom as Bishop: The View from Antioch, JEH 55 (2004) 464.

${ }^{12}$ Por. Joannes Chrysostomus, In Matthaeum hom. 7, 7, PG 57, 81, ŹMT 18, 100: „ «Cóż zatem, ktoś zapyta, każesz czynić? Wynosić się w góry i zostać pustelnikiem?» Właśnie dlatego najbardziej ubolewam, że uważacie, iż skromność i czystość im tylko przystoi, a przecież Chrystus wydał te same prawa dla wszystkich. [...] Przypatrz się zatem widowisku [Kazania na górze], a znienawidź tamto szatańskie [tj. teatr], i nie potępiaj powagi moich słów. [...] Nie nakazuję, abyście udawali się w góry i na pustynie, lecz mówię, by ten, kto mieszka w mieście, był dobry, przyzwoity i skromny. Wszystkie prawa mamy przecież wspólne z pustelnikami oprócz małżeństwa".

${ }^{13}$ Tenże, Adversus Iudaeos or. 8, 4, PG 48, 932, tłum. J. Iluk, ŹMT 41, Kraków 2007, 231. Mowy te zostały wygłoszone w Antiochii w latach 383-387. Por. Mayer, The Homilies of St John Chrysostom, s. 260 [CPG 4327]). Zob. Joannes Chrysostomus, De Lazaro con. 3, 1, PG 48, 992, A. Bober, w: AP, s. 95: „Niech mi tu nikt nie występuje z zimnymi i niemądrymi wymówkami: Jestem adwokatem, radnym, rzemieślnikiem, mam żonę i muszę zarabiać na wyżywienie dzieci, muszę prowadzić dom, jestem człowiekiem świeckim. Nie jest moim obowiązkiem czytanie Pisma Świętego. Niechaj zajmują się tym ci co usunęli się od świata, co po górach mieszkają i bezustannie żyją w samotności. - Co ty mówisz? Zajmowanie się Pismem Świętym nie jest ponoć twoim obowiązkiem, boś zaplątany w tysiączne kłopoty? Otóż właśnie dlatego powinieneś tym bardziej 
Nie dziwi zatem fakt, że antiocheńscy asceci, zarówno mężczyźni jak i kobiety, czynnie uczestniczyli w życiu Kościoła lokalnego: brali udział w nabożeństwach, czas spędzali na modlitwach i studiowaniu Pisma Świętego, najprawdopodobniej także podejmowali dzieła miłosierdzia. Pomimo tego zaangażowania religijnego nadal pozostawali „zwykłymi” chrześcijanami bardzo mocno osadzonymi w realiach miejskiej społeczności. Na ogół wywodzili się z wyższych warstw społecznych, co można wnioskować z faktu niepodejmowania przez nich pracy zarobkowej. Bardzo dobrym przykładem osoby praktykującej taką ascezę jest Jan Chryzostom, czy też inni uczniowie Diodora $\mathrm{z}$ Tarsu († przed 394) $)^{14}$ studiujący w tzw. asketerionie.

Funkcjonujący w Antiochii w drugiej połowie IV w. asketerion ${ }^{15}$ prowadzony przez Diodora z Tarsu i Karteriusza (IV w.), miał charakter szkoły prywatnej ${ }^{16}$. W tej szkole nauki pobierał m.in. wspomniany już Jan Chryzostom oraz dwaj jego koledzy ze szkoły Libaniusza - Maksym ${ }^{17}$ i Teodor ${ }^{18}$ (późniejszy biskup Mopsuestii; ok. 350-428). Szkoła ta była instytucją otwartą dla wszystkich chrześcijan, którzy chcieli pogłębić swą formację duchową i intelektualną.

W antiocheńskim asketerionie przede wszystkim oferowano wykształcenie w zakresie egzegezy Pisma Świętego oraz formację eklezjalną ${ }^{19}$. Egzegeza Pisma Świętego w asketerionie stała na bardzo wysokim poziomie, gdyż wykładana była przez jednego z najwybitniejszych egzegetów antiocheńskich - Diodora z Tarsu ${ }^{20}$. Wydaje się jednak, że przedmiotem badań był jedynie grecki tekst Biblii, gdyż z niektórych wypowiedzi Jana Chryzostoma wyni-

zainteresować się tym"; wygłoszenie tych homilii uczeni umieszczają miedzy 387 a 393 rokiem (por. Mayer, The Homilies of St John Chrysostom, s. 260 [CPG 4329]). Zob. Joannes Chrysostomus, In Matthaeum hom. 2, 5, PG 57, 30, ŹMT 18, 36; tenże, In epistulam ad Romanos hom. 23, 1, PG 60, 615, tłum. W. Sinko: Św. Jan Chryzostom, Homilie na list św. Pawła do Rzymian, oprac. A. Baron, t. 2, Kraków 1998, 360.

${ }^{14}$ Szerzej na temat Diodora zob. W. Kania, Diodor z Tarsu, EK III 1332; M. Simonetti, Diodoro di Tarso, NDPAC I 1426-1427.

${ }^{15}$ Szerzej na temat asketerionu zob. Festugière, Antioche païenne et chrétienne, passim (spec. rozdział V: Le rôle des monastères dans l'éducation selon Chrysostome, § 1. L'ascétérion de Diodore à Antioche, s. 181-192).

${ }^{16}$ Por. Socrates, HE VI 3, 6, éd. G.C. Hansen, SCh 505 (Livres: IV-VI), Paris 2006, 264-266, thum. S.J. Kazikowski: Sokrates Scholastyk, Historia Kościoła, Warszawa 1986, 450-451; Sozomenus, HE VIII 2, 5-6, éd. J. Bidez - G.C. Hansen, SCh 516 (Livres: VII-IX), Paris 2008, 236, thum. Kazikowski, s. 522. Zob. P. Canivet, Le monachisme syrien selon Théodoret de Cyr, Paris 1977, 50-51.

${ }^{17} \mathrm{Na}$ temat Maksyma wiadomo tylko tyle, że miał zostać biskupem Seleucji Izauryjskiej. Por. Kelly, Złote usta, s. 29.

${ }^{18}$ Szerzej na temat Teodora zob. M. Simonetti, Teodoro di Mopsuestia, NDPAC III 5252-5257; T. Skibiński, Teodor z Mopsuestii, EK XIX 624-626.

${ }^{19}$ Por. Sozomenus, HE VIII 2, 5-6, SCh 516, 236, thum. Kazikowski, s. 522: „On [tj. Jan Chryzostom] tymczasem postanowił zgłębić Pismo Święte i zająć się mądrością chrześcijańską zgodnie z uświęconym prawem Kościoła. Za nauczycieli tej mądrości miał ówczesnych kierowników słynących tam klasztorów, Karteriosa i Diodora, który stał na czele Kościoła w Tarsie”.

${ }^{20}$ Por. E. Schweizer, Diodor von Tarsus als Egseget, ZNW 40 (1941-1942) 33-37. 
ka, iż nie znał on hebrajskiego ${ }^{21}$, a podstawę analiz Pisma Świętego Starego Testamentu przeprowadzanych przez niego stanowił tekst Septuaginty ${ }^{22}$. Interesujące jest, że niekiedy jednak odwoływał się do niektórych sformułowań hebrajskich $^{23}$, czy syryjskich ${ }^{24}$.

Ponadto uczniowie asketerionu otrzymywali formację duchową o orientacji monastycznej. Jest faktem, że wielu absolwentów asketerionu weszło do grona duchownych, zwłaszcza ze stronnictwa biskupa Melecjusza (310$381)^{25}$, lecz na tej podstawie nie można wnioskować, że szkoła ta była instytucją stworzoną dla formacji kleru ${ }^{26}$. Sokrates Scholastyk charakteryzuje asketerion jako instytucję przygotowująca przede wszystkim do życia monastycznego ${ }^{27}$. Młodzi ludzie, którzy pragnęli uczęszczać do tej szkoły, byli wpi-

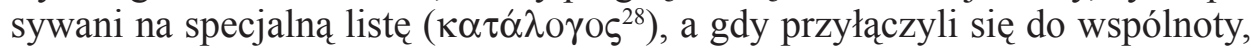
stawali się dla siebie nawzajem „braćmi” zobowiązanymi do zachowywania pewnego rodzaju umowy lub przymierza z Chrystusem $\left(\sigma v v \theta \eta \dot{\kappa} \kappa \eta^{29}\right)^{30}$. John

${ }^{21}$ Por. Joannes Chrysostomus, In Isaiam 7, 8, éd. J. Dumortier, SCh 304, Paris 1983, 330; tenże, In Genesim hom. 4, 4, PG 53, 24-25.

${ }^{22}$ Por. tenże, Expositio in Psalmum 121, 1, PG 55, 348, thum. W. Kania, w: Św. Jan Chryzostom, Homilie i kazania wybrane, PSP 8, Warszawa 1971, 45: „ «Jeruzalem, które się buduje jak miasto» [Ps 122(121), 3]. Inny tekst: «Zbudowane jak miasto». Albo więc to zdanie według Septuaginty znaczy, że Jerozolima zostanie zbudowana jak miasto, przez co zaznaczony jest czas, który poprzedza budowę, albo jak chce inny tłumacz: odzyskaliśmy Jeruzalem, «zbudowane jak miasto», co wskazuje na to, co zaszło po niewoli”.

${ }^{23}$ Por. tamże 7, 6. 10. 12, PG 55, 89. 96. 97. 99; 8, 7, PG 55, 116; 9, 3. 4. 7, PG 55, 126. 127, 132; 10, 2, PG 55, 143; 11, 4, PG 55, 148; 43, 6. 7. 8, PG 55, 176. 178. 179; 44, 9, PG 55, 197; 45, 1, PG 55, 203; 47, 2, PG 55, 219; 48, 2. 3, PG 55, 224. 226; 139, 2, PG 55, 422.

${ }^{24}$ Por. tamże 48, 3, PG 55, 226.

${ }^{25}$ Por. R. Nelz, Die theologischen Schulen der morgenländischen Kirchen während der sieben ersten christlichen Jahrhunderte in ihrer Bedeutung für die Ausbildung des Klerus, Bonn 1916, 51. Na temat Melecjusza zob. M. Simonetti, Melezio di Antiochia, NDPAC II 3190-3191; J. Czerwień, Melecjusz, EK XII 497.

${ }^{26}$ Por. Nelz, Die theologischen Schulen, s. 53.

${ }^{27}$ Por. Socrates, HE VI 3, 6, SCh 505, 264-266, thum. Kazikowski, s. 450-451: „Wtedy zaś usilnie pracując nad wewnętrznym udoskonaleniem zaprawiali się w ascezie pod kierunkiem Diodora i Karteriosa, którzy wówczas stali na czele klasztorów”. Zob. Nelz, Die theologischen Schulen, s. 51.

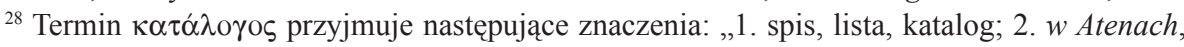
lista poborowa; 3. lista członków Rady" (Abramowiczówna II 589); por. Liddell - Scott, s. 899; Lampe, s. 711.

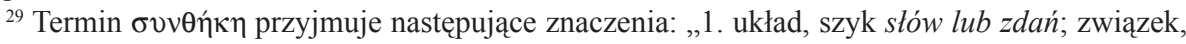
połączenie; 2. ugoda, umowa, układ" (Abramowiczówna IV 220); por. Liddell - Scott, s. 1717; Lampe, s. 1330-1331.

${ }^{30}$ Por. Joannes Chrysostomus, Ad Theodorum lapsum 2, 1, éd. J. Dumortier, SCh 117, Paris 1966, 46, thum. W. Kania: Do Teodora po jego upadku (List do mnicha Teodora zamierzajacego opuścić klasztor, pojać żonę i zajać się sprawami świata), w: Św. Jan Chryzostom, O malżeństwie, wychowaniu dzieci i ascezie, BOK 19, Kraków 2000, 125: „Gdyby łzy i westchnienia dały się wyrazić pismem, pełny ich list wysłałbym do ciebie. Płaczę, bowiem, nie dlatego, że nie jesteś przedmiotem ojcowskiej troski - lecz że się wykreśliłeś z listy braci ( $\tau 0 \hat{v} \kappa \alpha \tau \alpha \lambda o ́ \gamma o v \tau \hat{\omega} v \alpha \delta \varepsilon \lambda \varphi \hat{\omega} v$ ) i podeptałeś 
Norman Davidson Kelly zauważa, że zasady obowiązujące w asketerionie przywołują ,najważniejsze cechy charakteryzujące syryjskich «synów przymierza» ${ }^{31}$ i potwierdzają, że to oni stanowili wzór dla ascetycznego braterstwa, do którego należał Jan i kragg jego przyjaciół"32. Wprawdzie wspomniane tu cechy charakteryzujące antiocheński asketerion w pewnym sensie przypominają klasztor, jednak instytucja ta nim nie była: nie mieszkano w niej i nie prowadzono wspólnego życia monastycznego ${ }^{33}$, a pomimo tego w źródłach pojawia się pomieszanie tych kręgów ascetycznych z późniejszymi koncepcjami monastycyzmu, ponieważ $\mathrm{w}$ tamtych czasach monastycyzm był jedynym istniejącym paradygmatem ascezy ${ }^{34}$. Z dużym prawdopodobieństwem

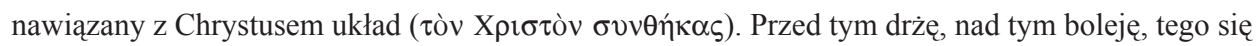
lękam, wiedząc, że wzgarda tych rzeczy gotuje wielką karę tym, którzy się oddali na tę świętą służbę i przez lekkomyślność porzucili swój obowiązek".

31 „Synowie przymierza” byli grupą mężczyzn „sprzymierzonych” w zorganizowanej, przedmonastycznej formie życia ascetycznego. Afrahat napisał o nich Mowę [Demonstratio Sexta. De monachis, ed. J. Parisot, w: Aphraatis Sapientis Persae Demonstrationes, PSyr 1, Paris 1894, 1980², 240-312, thum. A. Uciecha, Afrahat, O synach przymierza (Demonstratio Sexta. De monachis. PSyr 1, 240-312), SSHT 44 (2011) fasc. 1, 177-197 (tłumaczenie z języka syryjskiego i komentarz)]. Szerzej na ich temat zob. E.G.S. Jargy, Les „fils et filles du pacte” dans la littérature monastique syriaque, OCP 17 (1951) 304-320; A. Vööbus, The Institution of the „Benai Qeiama” and „Benat Qeiama” in the Ancient Syrian Church, ChH 30 (1961) 19-27; A. Uciecha, Rola i miejsce „synów przymierza” w Kościele perskim IV w. (na przyktadzie „Mów” Afrahata), VoxP 22 (2002) t. 4243, 161-175; tenże, Idea walki w ascezie „synów przymierza” na podstawie „Mów” Afrahata, w: Między sensem a bezsensem ludzkiej egzystencji. Teologiczna odpowiedź na fundamentalne pytania współczesnego człowieka. VIII Kongres Teologów Polskich (Poznań 13-16 IX 2010), Poznań 2012, 526-535; tenże, ,Walka” Złego z ,synami przymierza” na podstawie wybranych Mów Afrahata, perskiego Mędrca, VoxP 33 (2013) t. 59, 209-223; tenże, Sekrety duchowej walki w mowie „O wojnach" Afrahata, perskiego Mędrca, VoxP 35 (2015) t. 63, 389-396. Jednak nie tylko mężczyźni uprawiali ascezę. Ascetami były też kobiety, które nazywano „córkami przymierza”; por. tenże, Rola i znaczenie , córek przymierza” w Kościele Perskim IV i V wieku, VV 19 (2011) 233-246. Zob. J.M. Laboa, Mnisi Wschodu i Zachodu. Historia monastycyzmu chrześcijańskiego, thum. G. Jaworska - K. Malecha, Warszawa 2009, 32-33.

${ }^{32}$ Kelly, Ztote usta, s. 34.

${ }^{33}$ Por. J.H.W.G. Liebeschuetz, Ambrose and John Chrysostom: Clerics between Desert and Empire, Oxford 2011, 127-128. Jan Chryzostom, chociaż był uczniem tej szkoły, mieszkał ze swą matką w domu rodzinnym i w nim prowadził życie mnisze, por. Joannes Chrysostomus, De sacerdotio I 2, éd. A.-M. Malingrey, SCh 272, Paris 1980, 68-72, thum. W. Kania: Św. Jan Chryzostom, Dialog «O kapłaństwie», BOK 1, Kraków 1992, 45. Innego zdania jest R. Carter (Chrysoston's „,Ad Theodorum lapsum " and the Early Chronology of Theodore of Mopsuestia, VigCh 16:1961, 94-95), który twierdzi, że antiocheński asketerion funkcjonował na podobnych zasadach jak instytucja założona przez Bazylego Wielkiego.

${ }^{34}$ Por. Kelly, Złote usta, s. 30: „w oczach współczesnych jej członkowie [tj. szkoły Diodora] byli mnichami - monachoi: słowo to, podobnie jak jego syryjski odpowiednik khidaya, miało dużo szerszy zakres niż obecnie. Obejmowało swym znaczeniem nie tylko pustelników i wiernych zorganizowanych we wspólnoty, ale również żarliwych chrześcijan, którzy poruszając się po świecie usiłowali wieść życie jak najbardziej od niego oderwane i poświęcone Bogu”. Zob. G.M. Colombás, El concepto de monje y vida monastica hasta fines del siglo V, SMon 1 (1959) 338-342. 
można wnioskować, że uczniowie Diodora nie byli mnichami, lecz stanowili pewnego rodzaju „,bractwo zadeklarowanych, gorliwych chrześcijan, którzy pozostając $\mathrm{w}$ swoich domach i żyjąc $\mathrm{w}$ świecie postępowali według dobrowolnie narzuconych sobie rygorystycznych reguł wyrzeczenia" ${ }^{35}$. Taką właśnie orientację asketerionu potwierdza Jan Chryzostom, który kształcąc się w nim nie chciał być duchownym, lecz mnichem ${ }^{36}$. Złotousty wspomina też, że rozważał założenie ze swym towarzyszem Bazylim pewnego rodzaju domu ascetycznego, ale ostatecznie pozostał z matką, aż do czasu, gdy udał się w góry, aby tam zostać mnichem ${ }^{37}$.

W przekonaniu Chryzostoma życie poświęcone ascezie i studiom świętych ksiag było poważnym zobowiązaniem. Dlatego w upomnieniu skierowanym do swojego przyjaciela, Teodora (powszechnie utożsamianego z późniejszym biskupem Mopsuestii ${ }^{38}$ ), który opuścił wspólnotę ascetyczną, Chryzostom mówi o tym, że Teodor przez ten fakt wykreślił się z listy braci i podeptał nawiązany z Chrystusem układ ${ }^{39}$. Na ogół przyjmuje się, że stwierdzenia te wskazują na wycofanie się przez Teodora z grupy wspólnie praktykującej ascezę i prowadzącej życie quasi-monastyczne ${ }^{40}$. Wiele wskazuje na to, że ta forma życia ascetycznego była tylko okresowa, a nie stała i trwała, związana np. ze złożeniem jakichś ,ślubów”. W traktacie O kapłaństwie Chryzostom sugeruje, że stałą i długoterminową formę życia ascetycznego człowiek podejmuje wówczas, gdy decyduje się zostać kapłanem lub gdy opuszcza miasto i udaje się w góry, by zostać mnichem. On sam skosztowawszy życia mniszego, ostatecznie został duchownym, by służyć Kościołowi ${ }^{41}$.

Jeśli natomiast chodzi o kobiety uprawiające ascezę w ramach antiocheńskiej społeczności miejskiej, to posiadamy tylko szczątkowe informacje na ten temat. Nawet w rozprawie Jana Chryzostoma $O$ dziewictwie $e^{42}$ nie ma wiele informacji na temat sytuacji społecznej i życia codziennego ascetek-dziewic - jej adresatek. Chryzostom zauważa jedynie ich zaniedbane włosy, spuszczony wzrok i proste ubrania ${ }^{43}$. Natomiast w jednej z homilii na Ewangelię

\footnotetext{
${ }^{35}$ Kelly, Zlote usta, s. 30.

${ }^{36}$ Por. Palladius, Dialogus de vita Iohannis Chrysostomi 5, SCh 341, 108-110.

${ }^{37}$ Por. Joannes Chrysostomus, De sacerdotio I 2, SCh 272, 62-72, BOK 1, 44-46.

${ }^{38}$ Por. Kelly, Ztote usta, s. 33.

${ }^{39}$ Por. Joannes Chrysostomus, Ad Theodorum lapsum 2, 1, SCh 117, 46, BOK 19, 125.

${ }^{40}$ Por. Kelly, Złote usta, s. 33. Jednak nie dla wszystkich uczonych jest to oczywiste. Przykładowo Martin Illert (Johannes Chrysostomus und das antiochenisch-syrische Mönchtum. Studien zu Theologie, Rhetorik und Kirchenpolitik im antiochenischen Schriftum des Johannes Chrysostomus, Zurich 2000, 98-99) wskazuje, że w wypowiedzi Jana Chryzostoma istnieją wyraźne aluzje do sakramentu chrztu, a nie do życia quasi-monastycznego. Por. Laboa, Mnisi Wschodu i Zachodu, s. 33.

${ }^{41}$ Joannes Chrysostomus, De sacerdotio VI 2-7, SCh 272, 306-330, BOK 1, 130-136.

${ }^{42}$ Wydanie tekstu: H. Musurillo, SCh 125, Paris 1966. Na temat traktatu zob. B. Grillet, Introduction générale, $\mathrm{w}: \mathrm{SCh} 125,7-72$.

${ }^{43}$ Por. Joannes Chrysostomus, De virginitate 7, 1, SCh 125, 112.
} 
według świętego Mateusza ${ }^{44}$ Chryzostom wspomina o trzech tysiącach wdów i dziewic, którymi opiekował się Kościół antiocheński ${ }^{45}$, co wskazuje na obecność w mieście dziewic-ascetek oraz wdów, które najprawdopodobniej również praktykowały ascezę ${ }^{46}$. Wymieniając zaś w dialogu $O$ kapłaństwie różne zadania duszpasterskie biskupa, mówi o jego odpowiedzialności za formację dziewic, nad którymi powinien czuwać. Ta troska powinna wyrażać się m.in. w ograniczaniu ich kontaktu ze światem. Chryzostom mówi np. o zakazie wychodzenia na rynek, a nawet na pogrzeby i nocne nabożeństwa. Podkreśla, że dziewicy należy ,pilnować i rzadko w roku pozwalać jej na wychodzenie $\mathrm{z}$ domu, i to tylko w koniecznych wypadkach"47.

W Antiochii przyjął się też pewien specyficzny model życia ascetycznego nazywany synezaktem $\left(\sigma v v \varepsilon i ́ \sigma \alpha \kappa \tau o \varsigma^{48}\right)$, polegający na wspólnym zamieszkaniu dziewic poświęconych Bogu i mężczyzn - (duchownych lub świeckich) uprawiających ascezę ${ }^{49}$. Najstarsze znane użycie terminu $\sigma v v \varepsilon i ́ \sigma \alpha \kappa \tau o \varsigma$ związane jest właśnie z Antiochią i występuje w Liście synodalnym (przekazanym przez Euzebiusza z Cezarei) synodu antiocheńskiego $(268 / 269)^{50}$, a związane jest z potępieniem biskupa Pawła z Samosaty († po 272), oskarżanego m.in. o niemoralność, otoczonego - jak mówi List - przez „kobiety synaisaktai ( $\tau$ „às

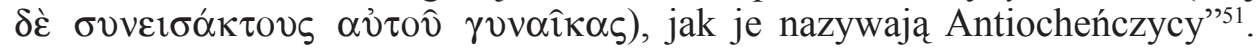
W tym miejscu warto zauważyć, że późniejsze pisma dotyczące ascetycznego życia dziewic w Antiochii i niebezpieczeństw jakie niesie ze sobą praktyka synezaktu ${ }^{52}$, pokazują, że ascetyzm ten był osadzony w normalnym życiu społecznym miasta.

${ }^{44}$ Jak już wspomniano Homilie na Ewangelię wedlug św. Mateusza zostały wygłoszone w Antiochii.

${ }^{45}$ Tenże, In Matthaeum hom. 66, 3, PG 58, 630, thum. J. Krystyniacki, ŹMT 23, Kraków 2001, 296: „Zwróć uwagę, ile Kośció - mający tyle dochodu co jeden z tych bogaczy i jeden człowiek posiadający średni majątek - utrzymuje dziennie wdów, ile kobiet, które ślubowały dziewictwo. Lista ich osiąga liczbę około trzech tysięcy".

${ }^{46}$ Por. Laboa, Mnisi Wschodu i Zachodu, s. 32: „Niektóre wdowy nie wychodziły za mąż, niektóre młode kobiety pozostawały niezamężne. Rola wdów i dziewic w życiu lokalnych Kościołów stała się bardziej widoczna, a swoboda modlitwy, postu i służby okazały się ich prawdziwym wkładem we wspólnotę wiary".

${ }^{47}$ Joannes Chrysostomus, De sacerdotio III 13, SCh 272, 216, BOK 1, 94.

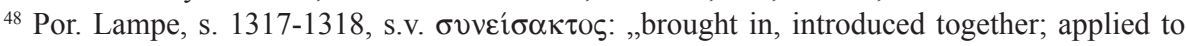
a virgin companion of a celibate man or conversely"; Liddell - Scott, s. 1705.

${ }^{49}$ Por. S. Longosz, Pisma przeciw synezaktom, VoxP 13-15 (1993-1995) t. 24-29, 337; W. Malej, Syneizakty, EK XVIII 1335.

${ }^{50}$ Był to ostatni synod zwołany w sprawie Pawła z Samosaty. Na synodzie tym złożono go $\mathrm{z}$ urzędu, a na biskupa Antiochii wybrano Domnosa.

${ }^{51}$ Concilium Antiochenum (268/269), Epistula synodalis, w: Eusebius Caesariensis, HE VII 30, 12, ed. i thum. ŹMT 70 [wyd. grecko-polskie, oprac. H. Pietras, thum. A. Caba na podstawie thum. A. Lisieckiego], Kraków 2013, 534-535.

${ }^{52}$ Por. Laboa, Mnisi Wschodu i Zachodu, s. 32. 
Praktyka synezaktu jest często wspominana we wczesnej literaturze chrześcijańskiej ${ }^{53}$. Wydaje się, że w tamtym czasie była ona znaczącym problemem, gdyż zakazywało jej ustawodawstwo kościelne. Synod w Elwirze (ok. 306), w kanonie 13. stwierdza to bardzo wyraźnie: „Zakazujemy dziewicom mieszkać z kimkolwiek jak siostra z bratem" ${ }^{54}$, zaś synod w Ancyrze (314) powtarza ten zakaz $^{55}$. Kwestia synezaktu była na tyle ważna, że zajęli się nią nawet Ojcowie Soboru Nicejskiego (325) uchwalając przeciw niej kanon 3. zatytuło-

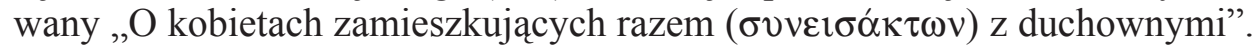
Stanowisko Ojców zostało wyrażone w następujących słowach: „Wielki sobór zabronił całkowicie biskupom, prezbiterom, diakonom i wszystkim członkom stanu duchownego, zamieszkiwać ( $\sigma v v \varepsilon i ́ \sigma \alpha \kappa \tau o v)$ z kobieta, chyba, że jest to matka, siostra, ciotka lub inna osoba stojąca poza wszelkimi podejrzeniami" ${ }^{56}$. Od tego czasu synezakt był powszechnie piętnowany jako nadużycie.

Przykładowo, Euzebiusz z Emesy (ok. 300-359), który przybył do Antiochii z Edessy, gdzie zapoznał się z syryjskimi wzorcami ascetycznymi dziewictwa i celibatu, potępił praktykę synezaktu w kazaniu, które - być może - wygłosił w Antiochii w latach 40. lub 50. IV wieku ${ }^{57}$. Natomiast Jan Chryzostom swe stanowisko na ten temat przedstawił w dwóch rozprawach (jednej

${ }^{53} \mathrm{Na}$ ten temat istnieje bogata literatura. Klasycznym opracowaniem jest monografia H. Achelis, Virgines subintroductae: ein Beitrag zum VII. kapitel des I. Korintherbiriefs, Leipzig 1902. Pisma przeciw synezaktom szczegółowo omawia S. Longosz (Pisma przeciw synezaktom, s. 337365). Por. R.E. Reynolds, Virgines subintroductae in Celtic Christianity, HTR 61 (1968) 547-566; A. Guillaumont, Le nom des ,,agapètes”, VigCh 23 (1969) 30-37; E.A. Clark, John Chrysostom and the ,Subintroductae”, ChH 46 (1977) 171-185 (spec. 171-175); R. Rader, Christian Pre-monastic Forms of Asceticism: Syneisaktism, or „Spiritual marriage”, w: The Continuing Quest for God: Monastic Spirituality in Tradition \& Transition, ed. W. Skudlarek, Collegeville 1982, 80-87; K. O'Brien Wicker, ,, The Politics of Paradise” Reconsidered: Chrysostom and Porphyry, w: Gnosticism and the Early Christian World, ed. J.E. Goehring - Ch.W. Hedrick - J.T. Sanders, Sonoma CA 1990, 116-133; B. Leyerle, John Chrysostom on the Gaze, JECS 1 (1993) 159-174; tenże, Theatrical Shows and Ascetic Lives. John Chrysostom's Attack on Spiritual Marriage, Berkeley - Los Angeles - London 2001, 79-86; H. Tamas - L. van der Sypt, Asceticism and syneisaktism in Asterius' ,'Liber ad Renatum monachum", ZACh 17 (2013) 504-525; L. van der Sypt, A Practical Solution to Late Antique Asceticism: Syneisaktism, StPatr 72 (2014) 211-217; C.L. De Wet, Revisiting the Subintroductae: Slavery, Asceticism, and „Syneisaktism” in the Exegesis of John Chrysostom, „Biblical Interpretation" 25 (2017) 58-80.

${ }^{54}$ Concilium Eliberitanum (circa 306) can. 13, ed. i tłum. ŹMT 37 [wyd. grecko-polskie, układ i oprac. A. Baron - H. Pietras, tłum. A. Baron - H. Pietras], SCL 1, Kraków 2006, 52-52*.

${ }_{55}$ Por. Concilium Ancyranum (314) can. 19, thum. S. Kalinkowski, SCL 1, 67-67*: „Zakazujemy dziewicom mieszkać z kimkolwiek jak siostra z bratem".

${ }^{56}$ Concilium Nicaenum (325) can. 3, ed. i thum. ŹMT 24 [wyd. grecko-łacińsko-polskie, układ i oprac. A. Baron - H. Pietras, thum. T. Wnętrzak], DSP 1, Kraków 2001, 28-29.

${ }^{57}$ Por. Eusebius Emesenus, Sermo 7, 20, ed. E.M. Buytaert, Eusèbe d'Émèse. Discours conservés en latin. Textes en partie inédits, t. 1: La collection de Troyes, Spicilegium Sacrum Louaniense 26, Louvain 1953, 188-189. Zob. D. Amand de Mendieta, La virginité chez Eusèbe d'Émèse et l'ascetismé familial dans la prèmiere moitié du IV siècle, RHE 50 (1955) 777-820; R.E. Winn, Eusebius of Emesa: Church and Theology in the Mid-Fourth Century, Washington 2011, passim. 
skierowanej do mężczyzn ${ }^{58}$, a drugiej skierowanej do kobiet ${ }^{59}$ ), prawdopodobnie zredagowanych w Antiochii ${ }^{60}$. Deprecjonujące nawiązanie do synezaktu z jednej z jego Homilii na Ewangelię wedtug św. Mateusza również odnosi się do sytuacji w Antiochii ${ }^{61}$. Godnym zaznaczenia jest fakt, że we wszystkich tych opisach zauważa się zupełny brak terminologii „monastycznej”: Chryzostom odnosi się do kobiet jako „dziewic”, a do mężczyzn jako „braci”.

2. Ascetyzm wiejski. Ascezę praktykowano nie tylko w mieście, lecz także w podantiocheńskich wioskach. Najbardziej intrygująca grupą związaną z ośrodkiem w Antiochii są ludzie ,ze wsi ( $\alpha \pi$ ò $\tau \hat{\eta} \varsigma \chi \omega ́ \omega \alpha \varsigma){ }^{\prime \prime 62}$, których Chryzostom szerzej wspomina w dwóch kazaniach: wygłoszonym w kwietniu roku $387^{63}$ i w kwietniu roku $391^{64}$. Nie ulega wątpliwości, że są oni ascetami ${ }^{65}$, ponieważ wyrzekają się wszystkich przyjemności miasta ${ }^{66}$, stronią od „roz-

${ }^{58}$ Joannes Chrysostomus, Contra eos qui subintroductas habent virgines, ed. J. Dumortier: Saint Jean Chrysostome, Les cohabitations suspectes. Comment observer la virginité, Paris 1955, 44-94, tłum. R. Sawa: Święty Jan Chryzostom, Przeciw duchownym mieszkajacym wspólnie z dziewicami, VoxP 13-15 (1993-1995) t. 24-29, 413-420 [wstęp], 421-446 [tekst].

${ }^{59}$ Joannes Chrysostomus, Quod regulares feminae viris cohabitare non debeant, éd. J. Dumortier: Saint Jean Chrysostome, Les cohabitations suspectes. Comment observer la virginité, s. 95137, tłum. R. Sawa: Święty Jan Chryzostom, Bogu poświęcone niewiasty nie powinny mieszkać z mężczyznami, VoxP 16 (1996) t. 30-31, 433-435 [wstęp], 435-460 [tekst].

${ }^{60}$ Por. J. Dumortier, La date des deux traités de saint Jean Chrysostome aux moines et aux vierges, MSR 6 (1949) 247-252.

${ }^{61}$ Por. Joannes Chrysostomus, In Matthaeum hom. 17, 2, PG 57, 256, ŹMT 18, 216. Jak już zaznaczono, homilie te były wygłoszone w Antiochii.

62 Joannes Chrysostomus, Ad populum Antiochenum hom. 19, tytuł, PG 49, 187, tłum. J. Iluk: Św. Jan Chryzostom, Mowy do Antiocheńczyków o posagach, Gdańsk 2017, 211; tenże, Catechesis ad illuminandos 8, 1, éd. A. Wenger, SCh 50bis, Paris 1970, 247, thum. W. Kania, w: Św. Jan Chryzostom, Katechezy chrzcielne (homilie katechetyczne do tych, którzy maja być oświeceni oraz do neofitów, U Źródeł Katechumenatu 1, Lublin 1993, 109.

${ }^{63}$ Tenże, Ad populum Antiochenum hom. 19, PG 49, 187-198. F. van de Paverd (St. John Chrysostom, The Homilies on the Statues. An Introduction, OCA 239, Roma 1991, 233-235) przekonująco datuje jej wygłoszenie na 12 kwietnia 387 r. (poniedziałek ostatniego tygodnia Wielkiego Postu); za nim J. Iluk, Wstęp, w: Św. Jan Chryzostom, Mowy do Antiocheńczyków o posagach, s. XX.

${ }^{64}$ Joannes Chrysostomus, Catechesis ad illuminandos 8, SCh 50bis, 248-260, thum. Kania, s. 109-118. Van de Paverd (St. John Chrysostom, The Homilies on the Statues, s. 255-260) w oparciu o analogie z wcześniejszą homilią datuje jej wygłoszenie na 12 kwietnia $391 \mathrm{r}$.

${ }^{65}$ Por. van de Paverd, St. John Chrysostom, The Homilies on the Statues, s. 262: „there can be no doubt that they lived as monks [...] Chrysostom names all of the topoi which are found in his texts on monastic life". W związku z tą informacją rodzi się pytanie, czy ascetów tych należy utożsamić z mnichami przywoływanymi przez Libaniusza (Oratio 30, 8-9 i 46-48, ed. R. Foerster, vol. 3 (Orationes XXVI-L), Lipsiae 1904, $91-92$ i 113-114, tłum. L. Małunowiczówna, w: Libanios, Wybór mów, Wrocław 2006, 232-333 i 251-252) w 386 r. jako przywódców niszczenia świątyń na wsi. Biorąc jednak pod uwagę jego komentarz, że mnisi byli „uciekinierami” z gospodarstw, którzy osiedlili się na „górze”, należy stwierdzić, że bardziej prawdopodobne jest, iż wskazywał na mnichów z góry Silpios.

${ }^{66}$ Por. Joannes Chrysostomus, Ad populum Antiochenum hom. 19, 1, PG 49, 188, thum. Iluk, 
pieszczonych kobiet, paradnych szat, pomadek i pomalowanych twarzy"67 oraz „zarzuciwszy pijaństwo i obżarstwo - jedzą tylko tyle, aby utrzymać się przy życiu”68, a przy tym „spędzają czas na śpiewaniu hymnów i modlitw, naśladując w ten sposób życie samych aniołów"69.

Z wypowiedzi Antiocheńczyka wynika, że dla mówiących po syryjsku ${ }^{70}$ rolników-ascetów okazją do brania udziału w pielgrzymkach do Antiochii były coroczne obchody ku czci świętych męczenników ${ }^{71}$. Kaznodzieja zawsze zauważał ich obecność i wyróżniał ich kierując pod ich adresem pochwały. Charakteryzował ich jako ludzi prostych, umiejących jedynie uprawiać ziemię, oderwanych od rzeczy doczesnych i myślących wyłącznie o sprawach duchowych $^{72}$. Pomimo tego, że posługują się zupełnie innym językiem - barbarzyńskim $^{73}$, to jednak sa prawdziwymi filozofami, w przeciwieństwie do filozofów działających w mieście, którzy nie mając pojęcia o sprawach nadprzyrodzonych jedynie są „dumni z brody i laski”74. O ich mądrości świadczą przyjęte przez nich idee oraz ich słowa i czyny ${ }^{75}$.

Chryzostom jednak nigdy nie nazywał owych ascetów mnichami ( $\mu$ ov $\alpha-$

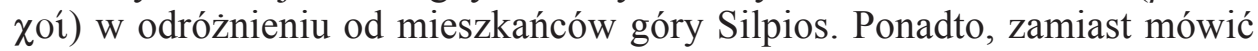
o praktykowanej przez nich kontemplacji, chwalił ich i stawiał jako przykłady ciężkiej pracy fizycznej, takiej jaką w raju podejmował Adam ${ }^{76}$, przez

s. 211: „Rzeczywiście, tam, gdzie mieszkają ci mężczyźni, nie ma nieprzyzwoitych widowisk, konnych wyścigów, nierządnic i miejskiego zgiełku”; tenże, Catechesis ad illuminandos 8, 4, SCh 50bis, 249, thum. Kania, s. 110: „Odrzucili oni bowiem wielki zbytek i wygody miasta”.

${ }^{67}$ Por. tenże, Ad populum Antiochenum hom. 19, 1, PG 49, 190, thum. Iluk, s. 213.

${ }^{68}$ Por. tamże; tenże, Catechesis ad illuminandos 8, 4, SCh 50bis, 249, tłum. Kania, s. 110: ,pożywają to, co jest niezbędne dla podtrzymania życia".

${ }^{69}$ Tenże, Catechesis ad illuminandos 8, 4, SCh 50bis, 249, thum. Kania, s. 110.

70 Tenże, Ad populum Antiochenum hom. 19, 1, PG 49, 188, tłum. Iluk, s. 211: „Odróżniają się oni od nas swoim językiem”. J. Iluk niniejszy tekst opatruje przypisem i wyjaśnia: „Ludność zamieszkująca okolice Antiochii posługiwała się językiem syryjskim” (tamże, nota 835).

${ }^{71}$ Por. Joannes Chrysostomus, Catechesis ad illuminandos 8, 1, SCh 50bis, 248, tłum. Kania, s. 109. A. Wenger (Introduction, w: SCh 50bis, s. 46) jest zdania, że być może chodzi o perskich chrześcijan, których męczeństwo miało miejsce za Szapura II (309-379) w Wielki Piątek 341 r. Zob. van de Paverd, St. John Chrysostom, The Homilies on the Statues, s. 291-292.

${ }^{72}$ Por. Joannes Chrysostomus, Catechesis ad illuminandos 8, 6, SCh 50bis, 249, thum. Kania, s. 110-111; tenże, Ad populum Antiochenum hom. 19, 1, PG 49, 188-189, thum. Iluk, s. 211-212.

${ }^{73}$ Por. tenże, Catechesis ad illuminandos 8, 2, SCh 50bis, 248, tłum. Kania, s. 109-110: „Nie patrzmy na to, że mają inną mowę, ale starajmy się zrozumieć mądrość ich dusz, pojmijmy głębię ich myśli, choć ją wyraża barbarzyński język”. Warto zauważyć, że sformułowanie „barbarzyński

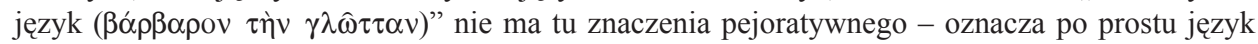
inny niż grecki.

${ }^{74}$ Por. tamże 8, 6, SCh 50bis, 250-251, thum. Kania, s. 111; tenże, Ad populum Antiochenum hom. 19, 1, PG 49, 189-190, thum. Iluk, s. 212-213.

${ }^{75}$ Por. tenże, Ad populum Antiochenum hom. 19, 1, PG 49, 189, tłum. Iluk, s. 212.

${ }^{76}$ Por. tamże, PG 49, 188-189, thum. Iluk, s. 211-212. Wprawdzie o pracy mnichów żyjących w górach mówi w podobny sposób, jednak nie podkreśla uciążliwości tej pracy, lecz stan bliskości z Bogiem: „Ich [tj. mnichów] praca jest taka sama jak ta, która zajmował się Adam na początku, za- 
co wypełniają ,apostolski nakaz starania się pracą rąk własnych o codzienne pożywienie (por. 1Kor 4, 12; Dz 20, 34)"'77. Ponadto z wypowiedzi Antiocheńczyka wynika, że asceci ci wypełniali obowiązki przynależne duchownym: czytali święte pisma i nauczali lud. Nawiązując do ich przybycia wraz z innymi mieszkańcami wsi na uroczystą liturgię sprawowaną w Antiochii, Chryzostom mówi:

„Można zobaczyć, jak każdy z nich stoi przy świętym ołtarzu ( $\pi \alpha \rho \grave{~} \tau$ ò $\beta \hat{\eta} \mu \alpha$

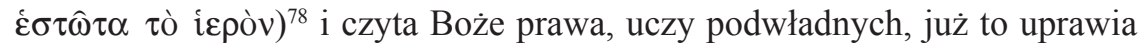
rolę, lemieszem orząc glebę, rzucając ziarno na jej łono, już to bierze do ręki pług i składa ziarno Bożych nauk w duszach uczniów"79.

W przytoczonym tekście można dostrzec odniesienie Chryzostoma do ludzi (najprawdopodobniej prezbiterów), którzy znajdowali się blisko $\beta \hat{\eta} \mu \alpha$ (termin określający bardziej ambonę, niż sam ołtarz - jak przełożył to ks. Wojciech Kania) i odczytywali fragmenty Pisma Świętego w języku, którym posługiwali się mieszkańcy wsi. Interesujące jest również przeplatanie przez kaznodzieję aluzji do ich pracy na roli i posługi duszpasterskiej, co wskazuje na fakt, że przybysze ci byli zarówno rolnikami, jak i kapłani, gdyż inaczej

nim zgrzeszył, gdy był przyodziany chwałą i swobodnie rozmawiał z Bogiem, i zamieszkiwał owo miejsce pełne wszelkiej szczęśliwości” (tenże, In Matthaeum hom. 68, 3, PG 58, 463, ŹMT 23, 317).

${ }_{77}^{77}$ Tenże, Catechesis ad illuminandos 8, 2, SCh 50bis, 248-249, thum. Kania, s. 110.

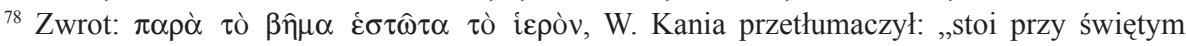
ołtarzu”. Przekład ten jest błędny, gdyż z kontekstu wypowiedzi wynika, że chodzi tu po prostu o ,ambonę”. Grecki rzeczownik $\beta \hat{\eta} \mu \alpha$ przyjmuje następujące znaczenia: „1. krok, stapanie, chód; 2. stopa, jako miara dlugości; 3. stopień, szczebel, siedzenie; 4. Wzniesienie, trybuna" (Abramowiczówna I 432); por. Lampe, s. 295: „A. step, going; hence 1. gait; 2. met. way of life; 3. pace; as mesure of lenght; B. platform; 1. rostrum; 2. tribunal of magistrate; 3. hence, met. legal business; judicial authority of a bishop; C. eccl. 1. tribune, chancel, sanctuary of church (i.e. raised platform whereon stood altar and seats of bishop ant other clergy, for whom access to it was exclusively reserved); of sanctuaries of martyrs; likened to place of Christ's session with apostles because of arrangement of presbyters 'seats on either side of bishop's chair; hence; 2. the clergy; of pagan 'clergy' instituted by Julian; 3. pulpit, placed in middle of church or nearer altar, from which Gospel and Epistle were read and sermons preached; D. (Manich.) focal object of ceremony at which passion of Moses was commemorated, and theme of Judgement emphasized, before judgement-seat containing picture of Moses and Manich. scriptures”; Liddell-Scott, s. 314: „I. 1. step, pace; footfall; gait; 2. step, as a mesure of length; 3. metaph. step, 'moment'; II. 1. step, seat; 2. a. raised place or tribune to speak from in a public assembly, etc; b. tribunal of a magistrate; 3. base, pedestal". Szerzej na ten temat zob. J. Dauvillier, L'ambon ou bêma dans les textes de l'Église chaldéenne et de l'Église syrienne au Moyen Âge, „Cahiers Archéologiques” 6 (1952) 11-30; R.G. Coquin, Le «bîma» des églises syriennes, OrSyr 10 (1965) 443-474.

${ }^{79}$ Joannes Chrysostomus, Catechesis ad illuminandos 8, 3, SCh 50bis, 249, tłum. Kania, s. 110. Podobna wypowiedź znajduje się w tenże, Ad populum Antiochenum hom. 19, 1, PG 49, 189, thum. Iluk, s. 212: „Tak też każdego z tych mężów zobaczysz, jak zaprzęga woły, a potem prowadzi pług

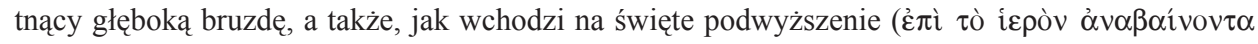
$\beta \widehat{\eta} \mu \alpha$ ), aby (z tego miejsca) niczym lemieszem przeorać dusze mu podwładnych. Innym razem (zobaczysz) jak sierpem wycina polne ciernie lub słowem oczyszcza duszę z grzechów”. 
nie mogliby wykonywać wyżej wspomnianych zadań duszpasterskich i pełnić funkcji kierowniczej wobec ludu ${ }^{80}$. Jednak warto zauważyć, że Jan Chryzostom nigdy nie odnosił się do nich jako do kapłanów (lub diakonów).

Warto również zastanowić się nad tym, z jakich środowisk (ascetycznych czy monastycznych) wywodzili się wspominani przez Chryzostoma rolnicy-kapłani. Udzielanie święceń ascetom, a nawet mnichom, aby mogli pełnić służbę Bożą, było praktyką znaną w starożytności, szczególnie na obszarach wiejskich. Dlatego też Frans van de Paverd jest zdania, iż jest bardzo możliwe, że wywodzili się ze środowiska monastycznego ${ }^{81}$, chociaż Chryzostom nigdy nie nazywa ich mnichami.

3. Monastycyzm „podmiejski”. W połowie IV w. można zauważyć w Antiochii pojawienie się nowego modelu ascezy (głównie w środowiskach syryjskich) związanego z mnichami-pustelnikami żyjącymi nie $\mathrm{w}$ mieście, lecz poza miastem - w podantiocheńskich górach. Przyjęta przez nich forma uprawiania ascezy jest wspominana przez Libaniusza, a dość szczegółowo przedstawiona przez Jana Chryzostoma i Teodoreta z Cyru. Dla nich styl życia mnichów był całkowitym przeciwieństwem stylu prezentowanego przez mieszkańców Antiochii, jednak odmienność tę różnie interpretowali. Dla Libaniusza mnisi stanowili zagrożenie dla wszystkich wartości hellenistycznego miasta, zaś dla Chryzostoma byli ideałami i figurami aniołów.

W Historia religiosa Teodoreta z Cyru przedstawione są biogramy kilku mnichów związanych ze środowiskiem monastycznym powstałym w podantiocheńskich górach Silpios i Staurin, które autor opisuje jako rozkwitające łąki na których przebywają ci, którzy dążą do osiągnięcia prawdziwej filozofii monastycznej ${ }^{82}$. Na szczególną uwagę zasługują wspomnienia o dwóch ascetach, których Teodoret znał osobiście ${ }^{83}$ : Macedoniuszu (ok. 325-417) i Piotrze Galacie (304/306-403/405), gdyż są oni najwcześniejszymi znanymi z imienia przedstawicielami tej formy monastycyzmu. Macedoniusz już od ok. roku 347 przebywał na górze Silpios, na której spędził 70 lat: przez 45 lat mieszkał

${ }^{80}$ Szczegółowe analizy tego problemu przedstawia van de Paverd (St. John Chrysostom, The Homilies on the Statues, s. 262-288) i konkludując, że byli „,co najmniej prezbiterami” (tamże, s. 263).

${ }^{81}$ Van de Paverd (tamże, s. 287) podsumowując swe rozważania na ten temat stwierdza: „«the men from the country» were monks who had received the laying on of hands and continued to live an ascetic life".

${ }^{82}$ Por. Theodoretus Cyrensis, HE IV 29(28), 3, ed. L. Parmentier - G.C. Hansen, SCh 530, Paris 2009, 308. Zob. Canivet, Le monachisme syrien selon Théodoret de Cyr, s. 157-163.

${ }^{83}$ Macedoniusz: Theodoretus Cyrensis, Historia religiosa 13, 1, ed. P. Canivet - A. Leroy-Molinghen, SCh 234, Paris 1977, 474, tłum. K. Augustyniak, ŹM 7, Kraków - Tyniec 1994, 184 : „Ja zaś mając więcej niż inni wiadomości o tym świętym człowieku [tj. Macedoniuszu] - wiele względów skłaniało mnie, aby do niego chodzić i często go widywać - opowiem wszystko szczegółowo, tak jak tylko potrafię”. Piotr (Galata), tamże 9, 4, SCh 234, 414, ŹMT 7, 162: „Ponieważ moja mataka [tj. matka Teodoreta] doświadczyła jego łaski duchowej, posyłała mnie do niego [tj. do Piotra (Galaty)] raz w tygodniu, aby mi udzielił błogosławieństwa”. 
„w głębokiej jamie”84, a przez 25 lat w ,szałasie i domkach, nie własnych jednak, ale cudzych" ${ }^{\prime 25}$. Natomiast Piotr Galata, gdy miał siedem lat rozpoczął życie ascetyczne w swych rodzinnych stronach - w Galacji, a następnie przybył do Palestyny, by w końcu osiąść pod Antiochią gdzie mieszkał w grobowcu mniej więcej od połowy IV wieku ${ }^{86}$.

W latach 60. IV w. mnisi uprawiający ascezę w podantiocheńskich górach byli już dość liczni. Do tego miejsca przybywali też asceci z dalszych stron. Przykładowo Teodoret odnotowuje przybycie z Edessy mnicha Afraatesa, z pochodzenia Persa, do Antiochii (ok. 360/361) ${ }^{87}$. Mówi też o wizycie mnicha Juliana (Saby), który ok. 365 r. przybył do Antiochii z Osroene ${ }^{88}$. Podantiocheńskich mnichów mieszkających w licznych pustelniach wspomina też Libaniusz w liście napisanym w listopadzie 363 r. Antiocheński retor pejoratywnie odnosi się do domniemanej negatywnej postawy mnichów wobec cesarza Juliana Apostaty, gdyby ten powrócił triumfalnie z wyprawy przeciw Persji; nawiązuje też do braku wykształcenia klasycznego i oratorskiego oraz posługiwania się przez mnichów językiem syryjskim, który uchodził za barbarzyński ${ }^{89}$.

Warto zauważyć, że w podantiocheńskich górach ascezę praktykowali nie tylko mężczyźni, lecz także kobiety. W jednej z homilii na List do Efezjan ${ }^{90}$ Chryzostom wspomina ascetki i mówi, że te młode dziewice (niektóre nie miały jeszcze dwudziestu lat), chociaż pochodziły z zamożnych rodzin i były wychowane w luksusie i zbytku, mając do dyspozycji wielu służących, porzuciły przepych swych domów rodzinnych i z miłości do Chrystusa udały się w góry. Teraz ubierają się w grube lniane ubrania, chodzą boso, śpią na łóżkach z liści, a większą część nocy spędzają na czuwaniach, posiłek spożywają tylko jeden raz dziennie (wieczorem), nieustannie krzątają się wykonując prace cięższe niż służący, opiekują się chorymi niewiastami, a nawet - co Chryzostom bardzo mocno akcentuje - gotują ${ }^{91}$. Obecność kobiet-ascetek w górach sugeruje, że dziewice te mogły być mniszkami, oficjalnie uznanymi przez Kościół, które podjęły stałe zobowiązanie do życia monastycznego.

${ }^{84}$ Tamże 13, 2, SCh 234, 476, ŹM 7, 184.

${ }^{85}$ Tamże, ŹM 7, 185.

${ }^{86}$ Por. tamże 9, 3, SCh 234, 410-412, ŹM 7, 161: „[Piotr] ukochał życie w samotności. Nie rozpiął jednak namiotu, nie wzniósł chaty, ani nie zbudował domku, lecz cały czas spędził w cudzym grobowcu. Grobowiec ten miał na górze piętro z rodzajem balkonu, do którego była przystawiona drabina dla tych, którzy chcieli wejść na górę. Zamknięty w tym grobowcu przeżył w nim większą część swego życia".

${ }^{87}$ Por. tamże 8, 1-2, SCh 234, 372-376, ŹM 7, 147-148.

${ }^{88}$ Por. tamże 2, 16, SCh 234, 230-232, ŹM 7, 94-95.

${ }^{89}$ Libanius, Epistula 1220, 5, ed. R. Foerster, vol. 11 (Epistulae 840-1544), Lipsiae 1922, 301.

${ }^{90}$ Homilie te zostały wygłoszone w Antiochii. Uczeni umieszczają ich wygłoszenie między 388 a 397 rokiem. Najważniejsze opinie na ten temat sumuje Wendy Mayer (The Homilies of St John Chrysostom, s. 268 [CPG 4431]).

${ }^{91}$ Por. Joannes Chrysostomus, In epistulam ad Ephesios hom. 13, 3, PG 62, 97-98. 
W latach 70-tych IV w., w czasie pobytu w Antiochii cesarza Walensa (328-378, cesarz od 364) dość często wspominanego przez Teodoreta z Cyru w Historia religiosa, wyraźnie daje się zauważyć wzrost liczby mnichów uprawiających ascezę w podantiocheńskich górach. W tym właśnie czasie rozpoczął też swe doświadczenie monastyczne Jan Chryzostom, który najpierw przez cztery lata (372-376) ${ }^{92}$ przebywał u pewnego pustelnika syryjskiego na górze Silpios, a następnie przez dwa lata prowadził samotnie surowe życie ascetyczne, co osłabiło jego zdrowie do tego stopnia, iż musiał powrócić do domu rodzinnego ${ }^{93}$.

To doświadczenie życia ascetycznego sprawiło, iż w wielu wypowiedziach Chryzostoma zawarty jest jego autentyczny podziw dla życia monastycznego. Bardzo często Złotousty przywoływał mnichów jako wzór do naśladowania i całkowite przeciwieństwo zabieganych i zatroskanych o tysiące ziemskich spraw mieszkańców Antiochii, do których kierował swe homilie ${ }^{94}$. Zachęcał też rodziców do wysyłania swych synów do podantiocheńskich pustelni, aby przez wspólne życie z mnichami zostali zabezpieczeni duchowo przed pokusami niesionymi przez życie $\mathrm{w}$ mieście ${ }^{95}$. O mnichach żyjących w podantiocheńskich górach, w zupełnym oderwaniu od miasta, wspominał też Libaniusz. Według niego, mnisi twierdzili, ,że w górach obcują (ó $\mu \imath \lambda \varepsilon \hat{\imath} v$ ) ze stwórcą wszechrzeczy"96. Z pism Libaniusza z lat 80-tych IV w. można

\footnotetext{
${ }^{92}$ Por. Kelly, Złote usta, s. 41 i 43.

${ }^{93}$ Por. Palladius, Dialogus de vita Iohannis Chrysostomi 5, 18-21, SCh 341, 108-110. Zob. Kelly, Złote usta, s. 43 i 48; W. Mayer, What Does It Mean to Say that John Chrysostom Was a Monk?, StPatr 41 (2006) 451-455.

${ }^{94}$ Por. Joannes Chrysostomus, De Lazaro con. 3, 1, PG 48, 992, AP, s. 95-96: „Albowiem tamci [tj. mnisi] nie potrzebują aż tak bardzo pociechy i pomocy Pisma Świętego, jak ci, których życie codzienne porywa wir przeróżnych zajęć. Właśnie dlatego powinieneś się więcej zająć Pismem Świętym, niż oni. Dla nich bowiem pociecha i pomoc Pisma Świętego nie jest tak konieczna, jak dla tych, co znajdują się w kłębowisku codziennych kłopotów. Do mnichów nie dociera rozgwar uliczny, bo domki pobudowali sobie na odludziu, z nikim się nie stykają, lecz zażywają doskonałego spokoju i ciszy, i czują się całkiem bezpieczni, jakby przybili do osłoniętego od wiatrów portu. My tymczasem jakby na pełnym morzu jesteśmy tam i tam rzucani i obracamy się wśród tysiącznych niebezpieczeństw grzechu, potrzebujemy więc ustawicznie pociechy i zachęty Pisma Świętego. Oni siedzą z dala od boju, dlatego też rzadko otrzymują razy. Ty zaś stoisz na pierwszej linii frontu i nowe rany otrzymujesz bez przerwy. Dlatego potrzebujesz więcej leków"; tenże, In Matthaeum hom. 55, 5-6, PG 58, 545-550; 68, 3-5, PG 58, 643-648; 69, 3-4, PG 58, 651-654; 70, 5, PG 58, 660 662; 72, 3-4, PG 58, 670-674; tenże, In epistulam I ad Timotheum hom. 14, 3-6, PG 62, 574-580; tenże, In epistulam ad Ephesios hom. 13, 3, PG 62, 97-98.

${ }^{95}$ Takie zachęty można znaleźć m.in. w traktacie Adversus oppugnatores vitae monasticae, którego redakcję datuje się na lata między 379 a 383 rokiem. Por. Kelly, Złote usta, s. 62.

${ }^{96}$ Libanius, Oratio 30, 48, ed. Foerster, vol. 3, s. 114, thum. Małunowiczówna, s. 252. Natomiast Chryzostom jest zachwycony mnichami, którzy nieustannie obcują z Bogiem: „Już tutaj

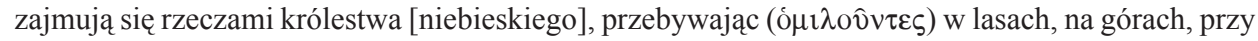
źródłach, w spokoju i głuchej samotności, a ponad to wszystko - razem z Bogiem" (In Matthaeum hom. 68, 3, PG 58, 643, ŹMT 23, 317) i którzy rozmyślają „o Bogu, o wszechświecie, o rzeczach
} 
wywnioskować, że w tym czasie wytworzył pewne standardowe tropy służące mu do charakteryzowania mnichów, których opisywał jako bladych ${ }^{97}$, odzianych w czarne szaty ${ }^{98}$ lub płaszcze żałobne (lub wory) ${ }^{99}$, mieszkających w górach ${ }^{100}$, grobach ${ }^{101} \mathrm{i}$ jaskiniach ${ }^{102}$, śpiewających hymny ${ }^{103}$ oraz oddających się pijaństwu ${ }^{104}$ i obżarstwu ${ }^{105}$.

Podantiocheńscy mnisi szybko zdobyli pozycję bardzo wpływowej grupy w społecznej strukturze miasta. Przyczyniło się do tego m.in. ich, wprawdzie rzadkie, aczkolwiek niezwykle skuteczne, włączanie się w ważkie sprawy społeczności miejskiej (zarówno religijne, jak i świeckie) ${ }^{106}$. Jan Chryzostom i Teodoret z Cyru opowiadają o roli mnichów, jaką odegrali w bardzo dramatycznej sytuacji, jaka zaistniała w Antiochii po rewolcie podatkowej związanej ze zniszczeniem posagów rodziny cesarskiej w 387 roku $^{107}$. Chryzostom podkreśla ${ }^{108}$, że mnisi ,porzucili swoje przybytki i groty, gdy tylko dostrzegli, że miasto pokrywają chmury. Kierowali się do miasta, spływając ze wzgórz niczym aniołowie z niebios" ${ }^{109}$. Można przypuszczać, że było

widzialnych i niewidzialnych, zmysłowych i duchowych, o znikomości tego życia i wielkości życia przyszłego" (tamże 68, 4, PG 58, 646, ŹMT 23, 320).

${ }^{97}$ Por. Libanius, Oratio 62, 10, ed. R. Foerster, vol. 4 (Orationes LI-LXIV), Lipsiae 1908, 351; 30, 8, ed. Foerster, vol. 3, s. 91.

${ }^{98}$ Por. tamże 30, 8, ed. Foerster, vol. 3, s. 91.

${ }^{99}$ Por. tamże 2, 32, ed. R. Foerster, vol. 1 (Orationes 1-11), Lipsiae 1903, 249; 30, 46, ed. Forster, vol. 3, s. 114 .

${ }^{100}$ Por. tamże 30, 48, ed. Foerster, vol. 3, s. 114.

${ }^{101}$ Por. tamże 62, 10, ed. Foerster, vol. 4, s. 351.

${ }^{102}$ Por. tamże 2, 32, ed. Foerster, vol. 1, s. 249; 45, 26, ed. Forster, vol. 3, s. 371-372.

${ }^{103}$ Por. tamże 30, 8, ed. Foerster, vol. 3, s. 91; 45, 26, ed. Forster, vol. 3, s. 371-372.

${ }^{104}$ Por. tamże 2, 32, ed. Foerster, vol. 1, s. 249; 30, 8, ed. Foerster, vol. 3, s. 91.

${ }^{105}$ Por. tamże 30, 8, ed. Foerster, vol. 3, s. 91, tłum. Małunowiczówna, s. 232: „A tymczasem ci oto ludzie [tj. mnisi], [...] żarłoczniejsi od słoni i mnogością wypijanych kubków sprawiający trud tym, którzy usługują im przy pijatyce wśród śpiewów, choć to nieumiarkowanie w jedzeniu i piciu ukrywają za pomocą bladości sztucznie wywoływanej".

${ }^{106}$ Jan Chryzostom nawiązując do roli mnichów, jaką odegrali w czasie śledztwa przeprowadzanego przez komisarzy cesarskich po rewolcie podatkowej (387), mówi: „Bojący się Boga mieszkańcy klasztorów [tj. podantiocheńscy mnisi], odważnie pojawiwszy się tutaj [tj. w Antiochii], o wszystkim decydowali" (Joannes Chrysostomus, Ad populum Antiochenum hom. 18, 4, PG 49, 186, thum. Iluk, s. 209).

${ }^{107}$ Sumarycznie sytuację tę opisuje Jan Iluk, Wstęp, w: Św. Jan Chryzostom, Mowy do Antiocheńczyków o posqgach, s. VII-X. Por. R. Browning, The Riot of A.D. 387 in Antioch. The Role of the Theatrical Claques in the Later Empire, JRS 42 (1952) 13-20; van de Paverd, St. John Chrysostom; D. French, Rhetoric and the rebellion of A.D. 387 in Antioch, „Historia” 47 (1998) 468-484; P. Filipczak, Bunty i niepokoje w miastach wczesnego Bizancjum (IV wiek n.e.), Byzantina Lodziensia 12, Łódź 2009, 81-100; P. Szczur, Rewolta podatkowa w Antiochii (387) w świetle przekazów Jana Chryzostoma i Libaniusza. Retoryka i fakty historyczne, „Roczniki Historii Kościoła” 1(56) (2009) 49-75.

${ }^{108}$ Rolę mnichów Chryzostom opisuje w Ad populum Antiochenum hom. 17, PG 49, 171-180, thum. Iluk, s. 191-201.

${ }^{109}$ Tamże 17, 2, PG 49, 173, thum. Iluk, s. 192. 
ich wielu, gdyż kaznodzieja twierdzi, że „miasto upodobniło się do nieba, gdyż wszędzie pojawiali się owi święci" ${ }^{110}$. Przybyli, aby bronić oskarżonych przed sądem komisarzy wysłanych przez cesarza. Interwencja mnichów była bardzo krótka, ale za to niezwykle skuteczna. Złotousty opisuje ją w zwięzłych słowach: „Dość było dla nich [tj. mnichów] jednego dnia, aby po zejściu (z gór) i spotkaniu z sędziami zakończyć prześladowania i powrócić do swych siedlisk"111. W czasie, gdy mnisi przybywali do Antiochii, filozofowie „opuścili miasto i poukrywali się w jaskiniach” ${ }^{112}$, które zwykle były siedzibą mnichów. Ta sytuacja stała się dla Chryzostoma okazją do kpin z tchórzliwych filozofów (te drwiny podobne są do pejoratywnych wypowiedzi Libaniusza na temat mnichów). Złotousty wyśmiewa ich ubiór (płaszcze i laski), wygląd (długie brody), obsesję na punkcie jedzenia oraz aktualne miejsca ich zamieszkania (jaskinie). Porównuje ich do cyników oraz psów i przeciwstawia im mnichów, którzy w dramatycznym dla miasta czasie ,zachowali się jak lwy"113.

Natomiast późniejszy przekaz Teodoreta, chociaż oparty na relacji Chryzostoma, koncentruje się jednak na roli jaką odegrał w tych wydarzeniach mnich Macedoniusz. Pomimo, iż Chryzostom w swym przekazie podkreśla rolę wielu mnichów, którzy w znacznej liczbie pojawili się w Antiochii, to jednak Teodoret mówi o osobistym charyzmacie Macedoniusza i właśnie jemu przypisuje kluczową rolę w ułaskawieniu mieszkańców Antiochii. W Historia religiosa dość szczegółowo opisuje jego spotkanie z komisarzami cesarskimi ${ }^{114}$ :

„Kiedy innym razem mieszkańcy Antiochii, ogarnięci szałem za sprawą złego ducha, zwrócili się przeciwko cesarskim posagom, do miasta przybyli wysocy urzędnicy, przynosząc dla niego wyrok zagłady. Wtedy Macedoniusz zszedł z góry i zatrzymał obydwóch urzędników, którzy przechodzili przez rynek. Gdy dowiedzieli się, kim jest, zeskoczyli z koni, ujęli go za ręce i kolana i pozdrowili. Poprosił ich, aby powiedzieli cesarzowi, iż jest człowiekiem i ma tę samą naturę, co ci, którzy go obrazili, i że gniew swój powinien mierzyć według swojej natury, tymczasem on przebiera w nim miarę i z powodu swoich własnych wizerunków zabija wizerunki Boga i dla posagów z brązu wydaje na śmierć ciała. «My - mówił - łatwo możemy odbudować i odtwo-

${ }^{110}$ Tamże. Nieco dalej Złotousty mówi: „Miasto niespodziewanie przemieniło się w klasztor” (tamże, PG 49, 175, thum. Iluk, s. 195).

${ }^{111}$ Tamże, PG 49, 174, thum. Iluk, s. 194.

112 Tamże, thum. Iluk, s. 193.

${ }^{113}$ Tamże, thum. Iluk, s. 194. Podobna ocena filozofów znajduje się w tamże 19, 1, PG 49, 190 , tłum. Iluk, s. 212: „Nic więc dziwnego, że niechrześcijańscy filozofowie nie są w niczym lepsi od aktorów i mimów, gdyż wyróżnia ich jedynie wytarty płaszcz, broda i odzież”.

${ }^{114}$ Czyni to również w swej Historii Kościoła. Por. Theodoretus Cyrensis, HE V 20, 5, SCh 530, 420, tłum. J. Iluk, w: Św. Jan Chryzostom, Mowy do Antiocheńczyków o posagach, s. 192-193, nota 759 . 
rzyć posagi w brązie, ale ty, nawet będąc cesarzem, nie zdołasz przywołać do życia ciał zabitych. Cóż ja mówię 'ciał', nawet jednego włosa przywrócić nie jesteś w stanie!»» ${ }^{115}{ }^{\prime 116}$.

Ponadto Teodoret podkreśla fakt, że Macedoniusz był człowiekiem prostym i przemawiał do urzędników w języku syryjskim ${ }^{117}$ oraz, że tak mądre słowa musiał wypowiedzieć pod natchnieniem Ducha Świętego, gdyż nie mógł ich sformułować „,człowiek pozbawionym wszelkiego wykształcenia, wychowany na wsi, żyjący na szczytach górskich, o wielkiej prostoduszności, nie obeznany ze słowami Pisma Świętego" "118.

Chociaż - jak już wspomniano - mnisi rzadko pojawiali się w Antiochii, to jednak zarówno Teodoret, jak i Libaniusz przekazują informacje na temat innych ich wizyt w mieście. Przykładowo - jak podaje Teodoret - wspomniany już mnich Julian (Saba), ok. 365 r. przybył do Antiochii, aby obalić pogłoski jakoby wyznawał arianizm ${ }^{119}$. Natomiast w biografii mnicha Afraatesa, Teodoret wspomina jego wizytę w Antiochii w roku $377^{120}$, w czasie wielkiego niepokoju w mieście i prześladowania nicejczyków, oraz spotkanie z cesarzem Walensem ${ }^{121}$. Mówi też, że chociaż mnich ten mieszkał poza miastem (do-

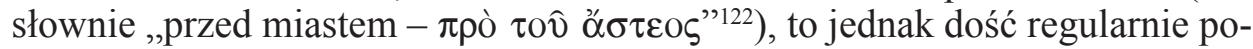
jawiali się u niego mieszkańcy Antiochii, w tym Teodoret ze swoją matką ${ }^{123}$ :

„Można było widzieć, jak schodzą się do niego urzędnicy, dostojnicy, dowódcy wojskowi, ale i ludzie żyjący z pracy własnych rąk, jednym słowem,

${ }^{115}$ Podobna mowa pojawia się w przekazie Chryzostoma, jednak autor nie wiąże jej bezpośrednio z postacią Macedoniusza. Por. Joannes Chrysostomus, Ad populum Antiochenum hom. 17, 2, PG 49, 173, tłum. Iluk, s. 192: „Opowiadano potem, że jeden (z mnichów) dodał pełne mądrości słowa: «Obalone posagi ustawiono na dawnym miejscu i przywrócono im wcześniejszy wygląd, a wszelkie sprawy szybko wyjaśniono. Natomiast, zniszczonego obrazu Boskiego nie przywrócicie do życia. Nie można wskrzesić tych, którzy zginęli, a duszę wprowadzić do ciała»”. Por. van de Paverd, St. John Chrysostom, The Homilies on the Statues, s. 69-72.

116 Theodoretus Cyrensis, Historia religiosa 13, 7, SCh 234, 486-488, ŹM 7, 188-189. Podobne opowiadanie Teodoret umieszcza w swej Historii Kościoła (HE V 20, 5, SCh 530, 420, thum. Iluk, w: Św. Jan Chryzostom, Mowy do Antiocheńczyków o posagach, s. 192-193, nota 759).

117 Tenże, Historia religiosa 13, 7, SCh 234, 488-490, ŹM 7, 189.

${ }_{118}$ Tamże 13, 8, SCh 234, 490, ŹM 7, 189.

${ }^{119}$ Por. tamże 2, 16-20, SCh 234, 230-232, ŹM 7, 94-98.

${ }^{120}$ Por. tamże 8, 5-10, SCh 234, 382-396, ŹM 7, 150-155.

${ }^{121}$ Por. tamże 8, 8, SCh 234, 388-392, ŹM 7, 153-154; tenże, HE IV 26, SCh 530, 300-304.

${ }^{122}$ Tenże, Historia religiosa 8, 2, SCh 234, 376, ŹM 7, 148. Należy zauważyć, że P. Canivet (Le monachisme syrien selon Théodoret de Cyr, s. 158-159) interpretuje tę informację jako wskazanie na teren pozamiejski, znajdujący się za północno-wschodnią bramą miasta. Jednak taka interpretacja wydaje się błędna, gdyż Teodoret dodaje, że w miejscu tym była „pewna szkoła filozoficzna” (tamże), co mogłoby wskazywać na teren położony w pobliżu Pola Marsowego, gdzie umiejscowiony też był antiocheński asketerion Diodora.

${ }^{123}$ Theodoretus Cyrensis, Historia religiosa 8, 15, SCh 234, 402, ŹM 7, 158: „Ja [tj. Teodoret] także go widziałem; miałem szczęście otrzymać błogosławieństwo z jego świętej ręki, gdy jeszcze jako chłopiec towarzyszyłem mojej matce, która go odwiedziła”. 
cywile i wojskowi, ludzie wykształceni i niewykształceni, żyjący w biedzie i opływający w bogactwa. Jedni słuchali jego słów w milczeniu, inni zadawali mu pytania i dochodzili prawdy dając mu okazję do wypowiedzi"

Libaniusz również wspomina o wizytach mnichów w mieście. W napisanej krótko przed rewoltą podatkową $(387)^{125}$ mowie $W$ sprawie więźniów, opisuje zachowanie niekompetentnego gubernatora - chrześcijanina Tisamenusa, który w momencie, gdy miał rozpocząć rozprawę sądową ,posłyszał, jak ludzie zamieszkujący w pieczarach, a wtedy tu przybyli, śpiewają swoje pieśni, co zwykle czynią latem, zerwał się z krzesła i jak najszybciej uszedł, jakby nie było rzeczą godziwą za ich zjawieniem się prowadzić jakieś postępowanie sądowe" 126 . Natomiast w słynnej mowie $W$ obronie światyń, napisanej w roku 384 lub 388 ${ }^{127}$, Libaniusz skarży się, że ,ludzie, w czarne ubrani szaty, [...] rzucają się na świątynie z kijami, z kamieniami, z drągami żelaznymi, niektórzy nawet bez niczego, tylko z gołymi rękami i nogami" ${ }^{128}$, a także „odważają się na to nawet w miastach, ale przede wszystkim na wsi" ${ }^{129}$. Warto też zwrócić uwage na odmienną ocenę mnichów: dla Jana Chryzostoma i Teodoreta byli charyzmatycznymi cudotwórcami, a dla Libaniusza - nieokrzesanymi fanatykami.

$\mathrm{O}$ dość bliskich relacjach mnichów z mieszkańcami Antiochii wspomina też Chryzostom. W jednej z homilii Ad populum Antiochenum ${ }^{130}$ mówi, że choć ,przebywają w swych samotniach na pobliskich wzgórzach" ${ }^{131}$ i ,zamieszkują pustynię"132, to jednak podkreśla, że ,mnisi zamieszkują miasto Antiocheńczyków"133. W nieco późniejszych homiliach na Ewangelię według św. Mateusza ${ }^{134}$ i na Pierwszy List do Tymoteusza ${ }^{135}$ zachęcał też mieszkań-

${ }^{124}$ Tamże 8, 2, SCh 234, 378, ŹM 7, 149.

${ }^{125}$ Por. Małunowiczówna, [Wstęp]: Mowa XLV. Do cesarza w sprawie więźniów, s. 256.

${ }^{126}$ Libanius, Oratio 45, 26, ed. Foerster, vol. 3, s. 371-372, thum. Małunowiczówna, s. 271-272.

${ }^{127}$ Por. Małunowiczówna, [Wstęp]: Mowa XXX. Do cesarza Teodozjusza w obronie światyń, s. 225.

${ }^{128}$ Libanius, Oratio 30, 8, ed. Foerster, vol. 3, s. 91, thum. Małunowiczówna, s. 232.

${ }^{129}$ Tamże 30, 9, ed. Foerster, vol. 3, s. 92, tłum. Małunowiczówna, s. 232-233.

${ }^{130}$ Homilie te zostały wygłoszone w Antiochii w roku 387. Por. Mayer, The Homilies of St John Chrysostom, s. 260 [CPG 4330]; Iluk, Wstęp, s. XV-XXI.

${ }^{131}$ Joannes Chrysostomus, Ad populum Antiochenum hom. 17, 1, PG 49, 172, thum. Iluk, s. 192.

${ }^{132}$ Tamże 17, 2, PG 49, 179, tłum. własne. Dokonano przekładu własnego, gdyż prof. Iluk grec-

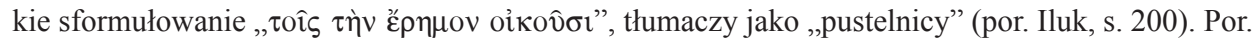
tamże, PG 49, 174, tłum. Iluk, s. 193: „koczujący na pustyniach”; tenże, In Matthaeum hom. 68, 3, PG 58, 463, ŹMT 23, 316: „mieszkający na pustyni”.

${ }^{133}$ Tenże, Ad populum Antiochenum hom. 17, 2, PG 49, 175, thum. własne. Dokonano przekła-

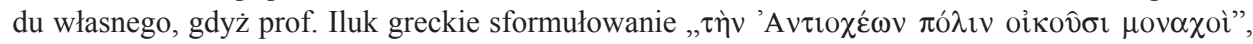
błędnie thumaczy i opuszcza słowo „oíkov̂бı” (por. Iluk, s. 195).

${ }^{134}$ Por. Joannes Chrysostomus, In Matthaeum hom. 68, 4, PG 58, 645, ŹMT 23, 319-320.

${ }^{135}$ Homilie te zostały wygłoszone w Antiochii. Uczeni umieszczają ich wygłoszenie między 394 a 397 rokiem. Najważniejsze opinie na ten temat sumuje Wendy Mayer (The Homilies of St John Chrysostom, s. 268 [CPG 4436]). 
ców miasta do odwiedzania mnichów, aby oderwać się od zgiełku miasta i zakosztować anielskiego spokoju. „Udaj się do namiotów świętych. Jak z ziemi do nieba, tak można schronić się do pustelni świętego" ${ }^{136}$. Tak właśnie czynił Teodoret jako młodzieniec, idąc za przykładem swej matki, która - chociaż była bezpłodna - dzięki modlitwie mnicha Macedoniusza poczęła dziecko. Kiedy zaś była już w piątym miesiącu ciąży groziło jej poronienie. Wówczas Macedoniusz przybył do niej, aby w cudowny sposób ją uzdrowić ${ }^{137}$. Matka Teodoreta wielkim szacunkiem i czcią otaczała też Piotra (Galatę), który uzdrowił ją z choroby oka ${ }^{138}$.

Przytoczone powyżej przykłady kontaktów mnichów ze społecznością Antiochii wyraźnie wskazują na ich zaangażowanie w życie miasta i jego mieszkańców. Prowadzi do wniosku, że stanowili integralną część społeczeństwa miejskiego.

\section{$* * *$}

Zaprezentowane powyżej analizy źródłowe jednoznacznie ukazują więc Antiochię i jej okolice jako ośrodek ascezy i życia monastycznego w drugiej połowie IV w. W tym czasie asceza była praktykowana przede wszystkim przez mieszkańców miasta (zarówno przez mężczyzn, jak i przez kobiety), chcących prowadzić pogłębione życie duchowe. Jednak podejmowali ją również mieszkańcy podantiocheńskich wiosek. Natomiast życie monastyczne, zwłaszcza w formie anachoreckiej, praktykowano poza miastem - w pobliskich górach, zwłaszcza na górze Silpios, która była wręcz wymarzonym miejscem dla ascetów i mnichów, gdzie znajdowali spokój i pełną intymność. Należy też zauważyć, że mnisi cieszyli się wśród mieszkańców Antiochii poważaniem i wielkim autorytetem, co sprawiało, że niekiedy naruszali zasadę oderwania od świata i życia w samotności przyjmując gości i - z ważnych powodów - odwiedzając miasto.

\section{ANTIOCH IN SYRIA AS AN ASCETIC AND MONASTIC CENTER IN THE SECOND HALF OF THE FOURTH CENTURY}

\section{(Summary)}

The article presents a particular phase in the evolution of Christian asceticism, as exemplified by the monastic-ascetic milieu of Syrian Antioch. The writings of John Chrysostom, Theodoret of Cyprus and Libanius, which all refer to ascetic and monastic life in Antioch and its environs in the second half of the fourth

\footnotetext{
${ }^{136}$ Tenże, In epistulam I ad Timotheum hom. 14, 3, PG 62, 575, thum. Sinko, s. 149.

${ }^{137}$ Por. Theodoretus Cyrensis, Historia religiosa 13, 16-17, SCh 234, 502-504, ŹM 7, 193-194.

${ }^{138}$ Por. tamże 9, 5-8, SCh 234, 414-422, ŹM 7, 162-164.
} 
century, are examined. These analyses allow us to identify three types among Antiochian ascetics. First group described included lay inhabitants of Antioch, both male and female, who endeavored to conduct a deeper spiritual life; this group included also persons practicing syneisaktism - a specific mode of ascetic life in which female virgins consecrated to God lived together with men (especially clergy) practicing ascesis. The second group consisted of rustic ascetics, to wit both lay and clergy inhabitants of villages around Antioch who conduced an ascetic lifestyle. The third group were those ascetics who observed monastic (or semi-monastic) life in the Antiochian mountains, especially on Mount Silpios. Monks were held in considerably high esteem, enjoying great respect among the inhabitants of Antioch. This resulted in their occasionally ignoring the rules of detachment from the world and of solitary life, as they entertained visitors or guests and - for serious reasons (e.g. during the trial of inhabitants of Antioch following the tax rebellion in 387) - visited the city. Our analysis thus depicts Antioch and its vicinity as a center of ascetic and monastic life. The clear-cut conclusion that emerges is that pre-monastic and monastic forms of ascetic life both existed in Antioch in the second half of the fourth century.

Key words: monasticism, asceticism, syneisaktism, Antioch in Syria, John Chrysostom, Theodoret of Cyrus, Libanius.

Słowa kluczowe: monastycyzm, asceza, synezakt, Antiochia Syryjska, Jan Chryzostom, Teodoret z Cyru, Libaniusz.

\section{BIBLIOGRAFIA}

\section{Źródła}

Afrates, Demonstratio Sexta. De monachis, ed. J. Parisot, w: Aphraatis Sapientis Persae Demonstrationes, PSyr 1, Paris 1894, 1980², 240-312, thum. A. Uciecha, Afrahat, O synach przymierza (Demonstratio Sexta. De monachis. PSyr 1, 240-312), SSHT 44 (2011) fasc. 1, 177-197 (tłumaczenie z języka syryjskiego i komentarz).

Concilium Ancyranum (314), Canones, ŹMT 37 [wyd. grecko-łacińsko-polskie, układ i opracowanie A. Baron - H. Pietras, tłum. S. Kalinkowski], SCL 1, Kraków 2006, 62-68*.

Concilium Antiochenum (268/269), Epistula synodalis, w: Eusebius Caesariensis, HE VII 29, 1 - 30, 17, ed. i thum. ŹMT 70 [wyd. grecko-polskie, oprac. H. Pietras, thum. A. Caba na podstawie tłum. A. Lisieckiego], Kraków 2013, 532-541.

Concilium Eliberitanum (circa 306), Canones, ŹMT 37 [wyd. grecko-polskie, układ i oprac. A. Baron - H. Pietras, tłum. A. Baron - H. Pietras], SCL 1, Kraków 2006, 49-61*.

Concilium Nicaenum (325), Canones, ŹMT 24 [wyd. grecko-łacińsko-polskie, układ i oprac. A. Baron - H. Pietras, tłum. T. Wnętrzak], DSP 1, Kraków 2001, 26-47.

Eusebius Emesenus, Sermones, ed. E.M. Buytaert, Eusèbe d'Émèse. Discours conservés en latin. Textes en partie inédits, t. 1: La collection de Troyes, Spicilegium Sacrum Louaniense 26, Louvain 1953.

JoAnnes Chrysostomus, Ad Demetrium de compunctione liber 1, PG 47, 393-410.

JoAnnes Chrysostomus, Ad populum Antiochenum hom, PG 49, 15-222, tłum. J. Iluk: Św. Jan Chryzostom, Mowy do Antiocheńczyków o posagach, Gdańsk 2017. 
Joannes Chrysostomus, Ad Theodorum lapsum libri 1-2, éd. J. Dumortier, SCh 117, Paris 1966, thum. W. Kania: Do Teodora po jego upadku (2. List do mnicha Teodora zamierzajacego opuścić klasztor, pojać żonę i zajać się sprawami świata; 1. Do Teodora po jego upadku i o pokucie), w: Św. Jan Chryzostom, O matżeństwie, wychowaniu dzieci $i$ ascezie, BOK 19, Kraków 2000, 125-178.

JoAnnes Chrysostomus, Adversus Iudaeos or., PG 48, 843-942, thum. J. Iluk, ŹMT 41, Kraków 2007.

Johnnes Chrysostomus, Adversus oppugnatores vitae monasticae, PG 47, 319-386.

Joannes Chrysostomus, Catecheses ad illuminandos, éd. A. Wenger, SCh 50bis, Paris 1970, tłum. W. Kania, w: Św. Jan Chryzostom, Katechezy chrzcielne (homilie katechetyczne do tych, którzy maja być oświeceni oraz do neofitów, U Źródeł Katechumenatu 1, Lublin 1993, 23-118.

Joannes Chrysostomus, Contra eos qui subintroductas habent virgines, ed. J. Dumortier: Saint Jean Chrysostome, Les cohabitations suspectes. Comment observer la virginité, Paris 1955, 44-94, tłum. R. Sawa: Święty Jan Chryzostom, Przeciw duchownym mieszkajacym wspólnie z dziewicami, VoxP 13-15 (1993-1995) t. 24-29, 413-420 [wstęp], 421-446 [tekst].

Joannes Chrysostomus, De Lazaro con., PG 48, 992, thum. fragmentu homilii 3, 1 A. Bober, w: AP, s. 95-96.

JoAnnes Chrysostomus, De sacerdotio, éd. A.-M. Malingrey, SCh 272, Paris 1980, tłum. W. Kania: Św. Jan Chryzostom, Dialog «O kapłaństwie», BOK 1, Kraków 1992.

Joannes Chrysostomus, De virginitate, éd. H. Musurillo, SCh 125, Paris 1966.

JoAnnes Chrysostomus, Expositiones in Psalmos, PG 55, 39-498, przekł. homilii na temat Psalmu 121 W. Kania, w: Św. Jan Chryzostom, Homilie i kazania wybrane, PSP 8, Warszawa 1971, 44-49.

JoAnnes Chrysostomus, In epistulam ad Ephesios hom., PG 62, 9-176.

JoAnnes Chrysostomus, In epistulam ad Romanos hom., PG 60, 391-682, thum. W. Sinko: Św. Jan Chryzostom, Homilie na list św. Pawta do Rzymian, oprac. A. Baron, t. 1-2, Kraków 1995-1998.

Jonnnes Chrysostomus, In epistulam I ad Timotheum hom., PG 62, 501-600, thum. T. Sinko, w: Św. Jan Złotousty, Homilie na Listy Pasterskie św. Pawła i na List do Filemona (Tym. I, II. Tyt. Filem.), przełożył i wstępem opatrzył T. Sinko, Kraków 1949, 25-192. JoAnnes Chrysostomus, In Genesim hom. PG 53, 21 - 54, 580.

Joannes Chrysostomus, In Isaiam, éd. J. Dumortier, SCh 304, Paris 1983.

JoAnnes Chrysostomus, In Matthaeum hom., PG 57, 13 - 58, 794, thum. J. Krystyniacki (homilie 1-40 i 61-90) - A. Baron (homilie 41-60): Św. Jan Chryzostom, Homilie na Ewangelię wedtug św. Mateusza, oprac. A. Baron, t. 1-2, ŹMT 18 i 23, Kraków 2000-2001.

JoAnnes Chrysostomus, Quod regulares feminae viris cohabitare non debeant, éd. J. Dumortier: Saint Jean Chrysostome, Les cohabitations suspectes. Comment observer la virginité, Paris 1955, 95-137, tłum. R. Sawa: Święty Jan Chryzostom, Bogu poświęcone niewiasty nie powinny mieszkać z mężczyznami, VoxP 16 (1996) t. 30-31, 433-435 [wstęp], 435-460 [tekst].

Libanius, Epistulae, ed. R. Foerster: Libanii Opera, t. 10: Epistulae 1-839, t. 11: Epistulae 840-1544. Una cum pseudoepigraphis et basilii cum Libanio commercio epistolico. Fragmenta, Bibliotheca Scriptorum Graecorum et Romanorum Teubneriana, Lipsiae 1921-1922.

Libanius, Orationes, ed. R. Foerster: Libanii Opera, t. 1-4, Bibliotheca Scriptorum Graecorum et Romanorum Teubneriana, Lipsiae 1903-1908, tłum. mów: 7, 11, 17, 25, 30, 45, 47, 57 i 64 L. Małunowiczówna, w: Libanios, Wybór mów, Wrocław 2006. 
Palladius, Dialogus de vita Iohannis Chrysostomi, ed. A.M. Malingrey - P. Leclercq, SCh 341, Paris 1988.

Socrates, Historia ecclesiastica, ed. G.C. Hansen, SCh 505 (Livres: IV-VI), Paris 2006, tłum. S.J. Kazikowski: Sokrates Scholastyk, Historia Kościoła, Warszawa 1986.

Sozomenus, Historia ecclesiastica, éd. J. Bidez - G.C. Hansen, SCh 495 (Livres: V-VI), Paris 2005; SCh 516 (Livres: VII-IX), Paris 2008, thum. S. Kazikowski: Hermiasz Sozomen, Historia Kościoła, Warszawa 1989.

Theodoretus Cyrensis, Historia ecclesiastica, ed. L. Parmentier - G.C. Hansen, SCh 530 (Livres III-V), Paris 2009.

Theodoretus Cyrensis, Historia religiosa, ed. P. Canivet - A. Leroy-Molinghen, SCh 234, Paris 1977, tłum. K. Augustyniak, ŹM 7, Kraków - Tyniec 1994.

\section{Opracowania}

Achelis H., Virgines subintroductae: ein Beitrag zum VII. kapitel des I. Korintherbiriefs, Leipzig 1902.

Amand de Mendieta D., La virginité chez Eusèbe d'Émèse et l'ascetismé familial dans la prèmiere moitié du IV siècle, RHE 50 (1955) 777-820.

Browning R., The Riot of A.D. 387 in Antioch. The Role of the Theatrical Claques in the Later Empire, JRS 42 (1952) 13-20.

Canivet P., Le monachisme syrien selon Théodoret de Cyr, Paris 1977.

CARTER R., Chrysoston's „, Ad Theodorum lapsum” and the Early Chronology of Theodore of Mopsuestia, VigCh 16 (1961) 87-101.

Clark E.A., John Chrysostom and the „, Subintroductae”, ChH 46 (1977) 171-185.

Colombás G.M., El concepto de monje y vida monastica hasta fines del siglo $\mathrm{V}$, SMon 1 (1959) 338-342.

CoQuin R.G., Le «bîma» des églises syriennes, OrSyr 10 (1965) 443-474.

Czerwień J., Melecjusz, EK XII 497.

DAuvillier J., L'ambon ou bêma dans les textes de l'Église chaldéenne et de l'Église syrienne au Moyen Âge, „Cahiers Archéologiques” 6 (1952) 11-30.

Downey G., A History of Antioch in Syria from Seleucus to the Arab Conquest, Princeton 1961.

Dumortier J., La date des deux traités de saint Jean Chrysostome aux moines et aux vierges, MSR 6 (1949) 247-252.

Festugière A.J., Antioche païenne et chrétienne. Libanius, Chrysostome et les moines de Syrie, Bibliothèque des Ecoles Françaises d'Athènes et de Rome, Fascicule 194, Paris 1959.

FiLIPCZAK P., Bunty i niepokoje w miastach wczesnego Bizancjum (IV wiek n.e.), Byzantina Lodziensia 12, Łódź 2009.

FRENCH D., Rhetoric and the rebellion of A.D. 387 in Antioch, „Historia” 47 (1998) 468-484.

Greek-English Lexicon, ed. H.G. Liddell - R. Scott, Oxford 1940.

GRILLET B., Introduction générale, w: SCh 125, 7-75.

Guillaumont A., Le nom des ,, agapètes”, VigChr 23 (1969) 30-37.

HadDad G., Aspects of Social Life in Antioch, Chicago 1949.

ILlERT M., Johannes Chrysostomus und das antiochenisch-syrische Mönchtum. Studien zu Theologie, Rhetorik und Kirchenpolitik im antiochenischen Schriftum des Johannes Chrysostomus, Zurich 2000.

ILuk J., Wstęp, w: Św. Jan Chryzostom, Mowy do Antiocheńczyków o posagach, s. VII-XIII.

JARGY E.G.S., Les ,fils et filles du pacte” dans la littérature monastique syriaque, OCP 17 (1951) 304-320.

Kania W., Diodor z Tarsu, EK III 1332. 
Kelly J.N.D., Złote usta. Jan Chryzostom - asceta, kaznodzieja, biskup, thum. K. Krakowczyk, Bydgoszcz 2001.

Laboa J.M., Mnisi Wschodu i Zachodu. Historia monastycyzmu chrześcijańskiego, tłum. G. Jaworska - K. Malecha, Warszawa 2009.

Lampe G.W.H., A Patristic Greek Lexikon, Oxford 1976.

LeYerLe B., John Chrysostom on the Gaze, JECS 1 (1993) 159-174.

Leyerle B., Theatrical Shows and Ascetic Lives. John Chrysostom's Attack on Spiritual Marriage, Berkeley - Los Angeles - London 2001.

Liebeschuetz J.H.W.G., Ambrose and John Chrysostom: Clerics between Desert and Empire, Oxford 2011.

Longosz S., Pisma przeciw synezaktom, VoxP 13-15 (1993-1995) t. 24-29, 337-376.

Malej W., Syneizakty, EK XVIII 1335.

MAYer W., John Chrysostom as Bishop: The View from Antioch, JEH 55 (2004) 455-466.

Mayer W., The Homilies of St John Chrysostom: Provenance. Reshaping the Foundations, OCA 273, Rome 2005.

Mayer W., What Does It Mean to Say that John Chrysostom Was a Monk?, StPatr 41 (2006) 451-455.

Nelz R., Die theologischen Schulen der morgenländischen Kirchen während der sieben ersten christlichen Jahrhunderte in ihrer Bedeutung für die Ausbildung des Klerus, Bonn 1916.

O'Brien Wicker K., ,, The Politics of Paradise” Reconsidered: Chrysostom and Porphyry, w: Gnosticism and the Early Christian World, ed. J.E. Goehring - Ch.W. Hedrick J.T. Sanders, Sonoma CA 1990, 116-133.

Paverd F. van DE, St. John Chrysostom, The Homilies on the Statues. An Introduction, OCA 239, Roma 1991.

RAder R., Christian Pre-monastic Forms of Asceticism: Syneisaktism, or „, Spiritual marriage”, w: The Continuing Quest for God: Monastic Spirituality in Tradition \& Transition, ed. W. Skudlarek, Collegeville 1982, 80-87.

Reynolds R.E., Virgines subintroductae in Celtic Christianity, HTR 61 (1968) 547-566.

Roux G., Mezopotamia, tłum. B. Kowalska - J. Kozłowska, Warszawa 1998.

Sachs A.J. - Wiseman D.J., A Babylonian King List of the Hellenistic Period, „Iraq” 16 (1954) 202-211.

Schweizer E., Diodor von Tarsus als Egseget, ZNW 40 (1941-1942) 33-37.

Simonetti M., Diodoro di Tarso, NDPAC I 1426-1427.

Simonetti M., Melezio di Antiochia, NDPAC II 3190-3191.

Simonetti M., Teodoro di Mopsuestia, NDPAC III 5252-5257.

SkIBIŃski T., Teodor z Mopsuestii, EK XIX 624-626.

Stownik grecko-polski, red. Z. Abramowiczówna, I-IV, Warszawa 1958-1965.

SyPt L. VAn DER, A Practical Solution to Late Antique Asceticism: Syneisaktism, StPatr 72 (2014) 211-217.

SzczuR P., Rewolta podatkowa w Antiochii (387) w świetle przekazów Jana Chryzostoma i Libaniusza. Retoryka i fakty historyczne, „Roczniki Historii Kościoła” 1(56) (2009) 49-75.

TAmas H. - SyPt L. VAn DeR, Asceticism and syneisaktism in Asterius' , ,Liber ad Renatum monachum", ZACh 17 (2013) 504-525.

TiERsCH C., Johannes Chrysostomus in Konstantinopel (398-404). Weltsicht und Wirken eines Bischofs in der Hauptstadt des Oströmischen Reiches, Studien und Texte zu Antike und Christentum 6, Tübingen 2002. 
UCIECHA A., ,Walka” Złego z , synami przymierza” na podstawie wybranych Mów Afrahata, perskiego Mędrca, VoxP 33 (2013) t. 59, 209-223.

UCIECHA A., Idea walki w ascezie , synów przymierza” na podstawie „,Mów” Afrahata, w: Między sensem a bezsensem ludzkiej egzystencji. Teologiczna odpowiedź na fundamentalne pytania współczesnego człowieka. VIII Kongres Teologów Polskich (Poznań 13-16 IX 2010), Poznań 2012, 526-535.

UCIECHA A., Rola i miejsce ,synów przymierza” w Kościele perskim IV w. (na przykładzie „Mów” Afrahata), VoxP 22 (2002) t. 42-43, 161-175.

Uciecha A., Rola i znaczenie ,córek przymierza” w Kościele Perskim IV i V wieku, VV 19 (2011) 233-246.

Uciecha A., Sekrety duchowej walki w mowie „O wojnach” Afrahata, perskiego Mędrca, VoxP 35 (2015) t. 63, 389-396.

Vööвus A., The Institution of the „Benai Qeiama” and „Benat Qeiama” in the Ancient Syrian Church, ChH 30 (1961) 19-27.

Wenger A., Introduction, w: SCh 50bis, Paris 1970, 7-107.

Wet C.L. De, Revisiting the Subintroductae: Slavery, Asceticism, and ,Syneisaktism” in the Exegesis of John Chrysostom, „Biblical Interpretation” 25 (2017) 58-80.

WINN R.E., Eusebius of Emesa: Church and Theology in the Mid-Fourth Century, Washington 2011. 
